\title{
Historia de dos industrias: un debate en torno a la historieta argentina y española (II)
}

\section{Amadeo Gandolfo, Pablo Turnes y Gerardo Vilches}

\begin{abstract}
Amadeo Gandolfo (1984) es licenciado en Historia y doctor en Ciencias Sociales. Realizó su doctorado como becario del Consejo Nacional de Investigaciones Científicas y Técnicas (CONICET) y actualmente es becario posdoctoral por la misma institución. Se desempeña como Jefe de Trabajos Prácticos en la materia «El Lado B de la Sociología: nuevas sociologías pragmático-pragmatistas y su reencuentro con viejas tradiciones», optativa de la Carrera de Sociología de la Universidad de Buenos Aires. Fue miembro organizador del Congreso Internacional Viñetas Serias en su más reciente edición (2014). Participa en el Área de Narrativas Dibujadas de la Carrera de Comunicación en la UBA, bajo la dirección de Laura Vazquez. Brinda talleres de crítica de historieta junto a Pablo Turnes con quien edita la revista de crítica de historietas Kamandi. Escribe y mantiene el blog El Baile Moderno desde el año 2007. Publicó en Crisis, Los Inrockuptibles, Mancilla, Haciendo Cine y otros medios. Asimismo, ha publicado en revistas y libros de carácter académico de Argentina, Brasil, Bélgica y Estados Unidos.
\end{abstract}

Pablo Turnes (1979) es profesor en Historia por la Universidad Nacional de Mar del Plata, magíster en Historia del Arte argentino y latinoamericano por el Instituto de Altos Estudios Sociales - Universidad Nacional de San Martín y doctor en Ciencias Sociales por la Universidad de Buenos Aires. Realizó su doctorado como becario del Consejo Nacional de Investigaciones Científicas y Técnicas (CONICET) y actualmente es becario posdoctoral por la misma institución. Se desempeña como Jefe de Trabajos Prácticos de la cátedra Historia de los medios de comunicación nacional y latinoamericana, en la Universidad Nacional de Moreno. Fue miembro organizador del Congreso Internacional Viñetas Serias en sus tres ediciones (2010, 2012 y 2014). Participa en el Ârea de Narrativas Dibujadas de la carrera de Comunicación en la UBA, bajo la dirección de Laura Vázquez. Brinda talleres de crítica de historieta junto a Amadeo Gandolfo, con quien además co-edita la revista web Kamandi. Ha participado de diferentes compilaciones y ha publicado numerosos artículos en revistas académicas y de divulgación. Su tesis de maestría será editada por Tren en Movimiento bajo el título El exilio de las formas. Alack Sinner de José Muñoz y Carlos Sampayo. Su tesis de doctorado se titula La excepción en la regla. La obra bistorietística de Alberto Breccia (1962-1993). 
Gerardo Vilches (1980) es licenciado en Historia (UCM) y máster en Métodos y técnicas de investigación (UNED). Actualmente, ha finalizado su tesis doctoral sobre el proceso político de la transición española a través de las revistas satíricas. Es profesor en la Universidad Europea de Madrid. Es autor de Breve historia del cómic (Nowtilus, 2014) y El guión de cómic (Diminuta, 2016). Codirige CuCo, Cuadernos de cómic_y es parte de la organización de GRAF un encuentro de cómic de autor y edición independiente. Ha colaborado en las antologías de ensayos Radiografías de una explosión, Hijos del átomo, El cómic digital hoy y Cómics Esenciales. Anuario 2016. Ha participado con sus textos en antologías de cómic como Panorama. La novela gráfica española hoy y Hoodoo Voodoo. Ha participado con ponencias y comunicaciones en diversos congresos, jornadas y cursos universitarios, y publicado artículos en revistas científicas, como Historia del presente. Es colaborador de medios como Rockdelux, Canino, Cactus, Las calles de Venecia o Kamandi. Formó parte del blog de referencia Entrecomics entre 2011 y 2016. Mantiene su blog de crítica y análisis, The Watcher and the Tower, desde 2007.

Fecha de de recepción: 20 de noviembre de 2017

Fecha de aceptación definitiva: 14 de diciembre de 2017 
Este texto es la segunda parte de un debate que comenzó en $\mathrm{CuCo}$, Cuadernos de cómic $n .^{\circ} 8$.

Pablo Turnes: Yo creo que en Argentina también se experimentó ese «desfasaje» respecto a la producción de los centros de la historieta de autor, que eran básicamente dos: Francia e Italia. Algo se había dado a conocer de Crepax por la revista de Masotta, $L D$, pero duró tres números entre fines de 1968 y principios de 1969. Hubo que esperar hasta 1974, cuando salió Skorpio y comenzó a publicarse por primera vez La balada del mar salado de Pratt, diez años después de haberse comenzado a publicar en Italia.

Skorpio fue importante porque logró consolidarse como un proyecto editorial-empresarial que se sostuvo en el tiempo, y podía hacerlo porque era básicamente una usina de producir buen material, pagarlo barato y venderlo a la casa matriz en Italia, a la editorial Eura, que publicaba la versión italiana de Skorpio. Así que esa modernización o «actualización» de la historieta viene al precio de asentar un modelo productivo periférico y dependiente de los editores europeos.

Siempre es algo contradictorio: Alfredo Scutti, el editor de Ediciones Récord y el intermediario con Italia, era sin dudas un personaje nefasto, que explotaba a los dibujantes y se quedaba con la diferencia entre lo que les pagaba y lo que ganaba vendiendo ese material en moneda extranjera.

Al mismo tiempo, la primera etapa de Skorpio — entre 1974 y 1980 - es de una gran riqueza creativa, mezclando artistas jóvenes, como Trillo, Juan Zanotto, Domingo Mandrafina o Enrique Breccia, con clásicos, como Oesterheld y Solano López — quienes publicaron ahí El Eternauta II, que seguía saliendo en los quioscos cuando el guionista ya estaba desaparecido- y Pratt y Alberto Breccia, es decir, la vieja guardia de Frontera. Existía una idea de recuperar esa tradición con las limitaciones antes señaladas.

El papel de Trillo es muy interesante, porque tanto él como Altuna venían de la publicidad, pero al mismo tiempo habían sido lectores de historieta y pertenecían a una generación más politizada y con otras perspectivas culturales de las que sus antecesores habían podido tener, en general gente más humilde y con una formación y una oferta cultural bien distinta.

Por un lado, Trillo empieza a lo grande en la historieta: hace «Un tal Daneri» con Alberto Breccia en 1974, en Sancho y Mengano, pero la historia de su publicación es bastante fragmentaria y caótica. De hecho, algunos episodios no se conocieron hasta mucho después en Argentina, lo cual habla de las dificultades de mantener una regularidad en el mercado local fuera de las pocas revistas que existían.

Por otro lado, no se limitó a ser el guionista de muchísimas historietas en simultáneo —algo así como un heredero de Oesterheld—, sino que, junto con Guillermo Saccomanno, tenían 

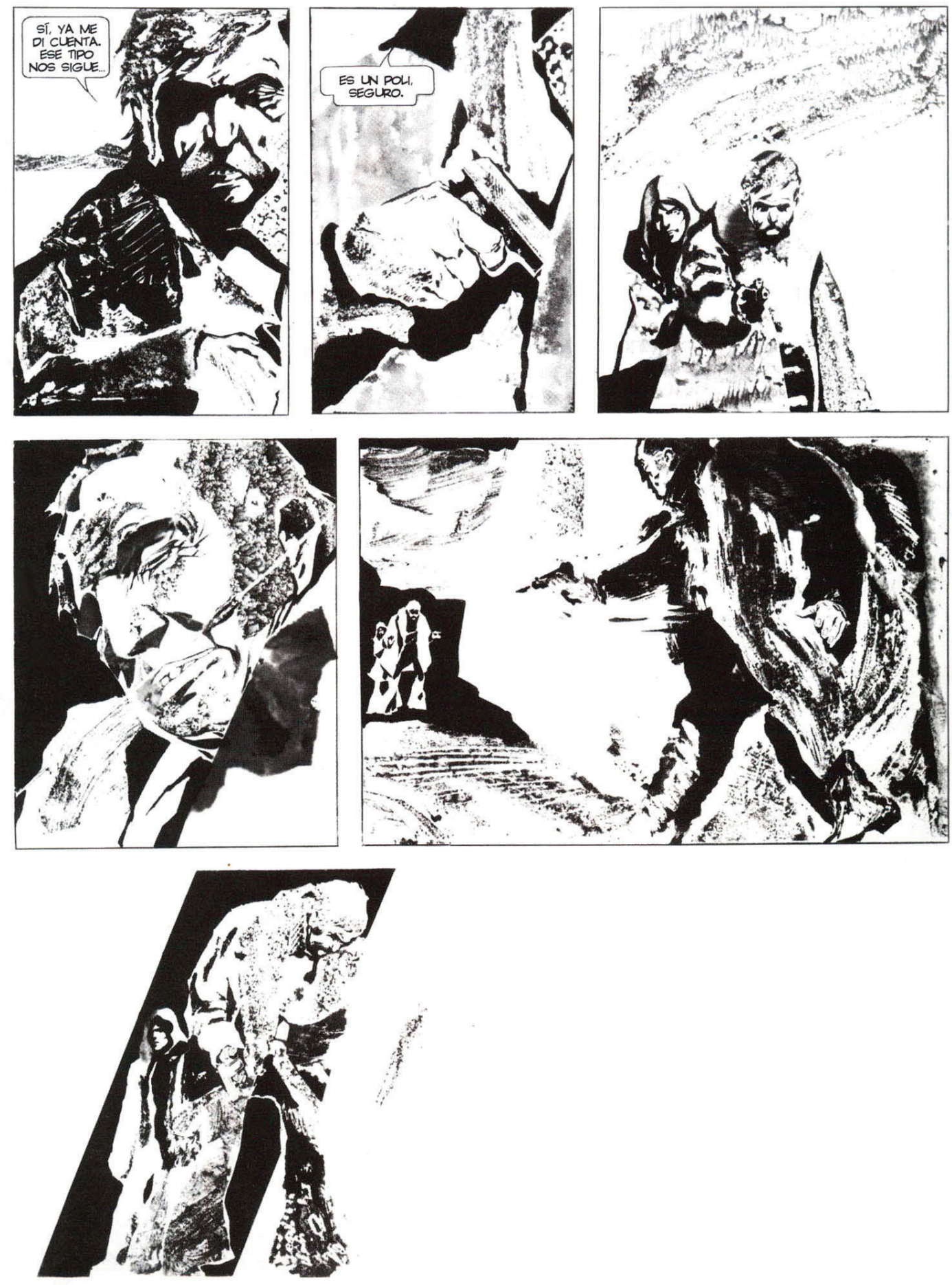

FIG. 1. Breccia, A. y Trillo, C. «Un tal Daneri», en Sancho y Mengano 5 (1974). 
una columna llamada «El Club de la historieta», en Skorpio, donde construyeron una historia de la historieta argentina — recopilada en el libro homónimo de 1980—, y de alguna manera marcaron por primera vez un canon retrospectivo.

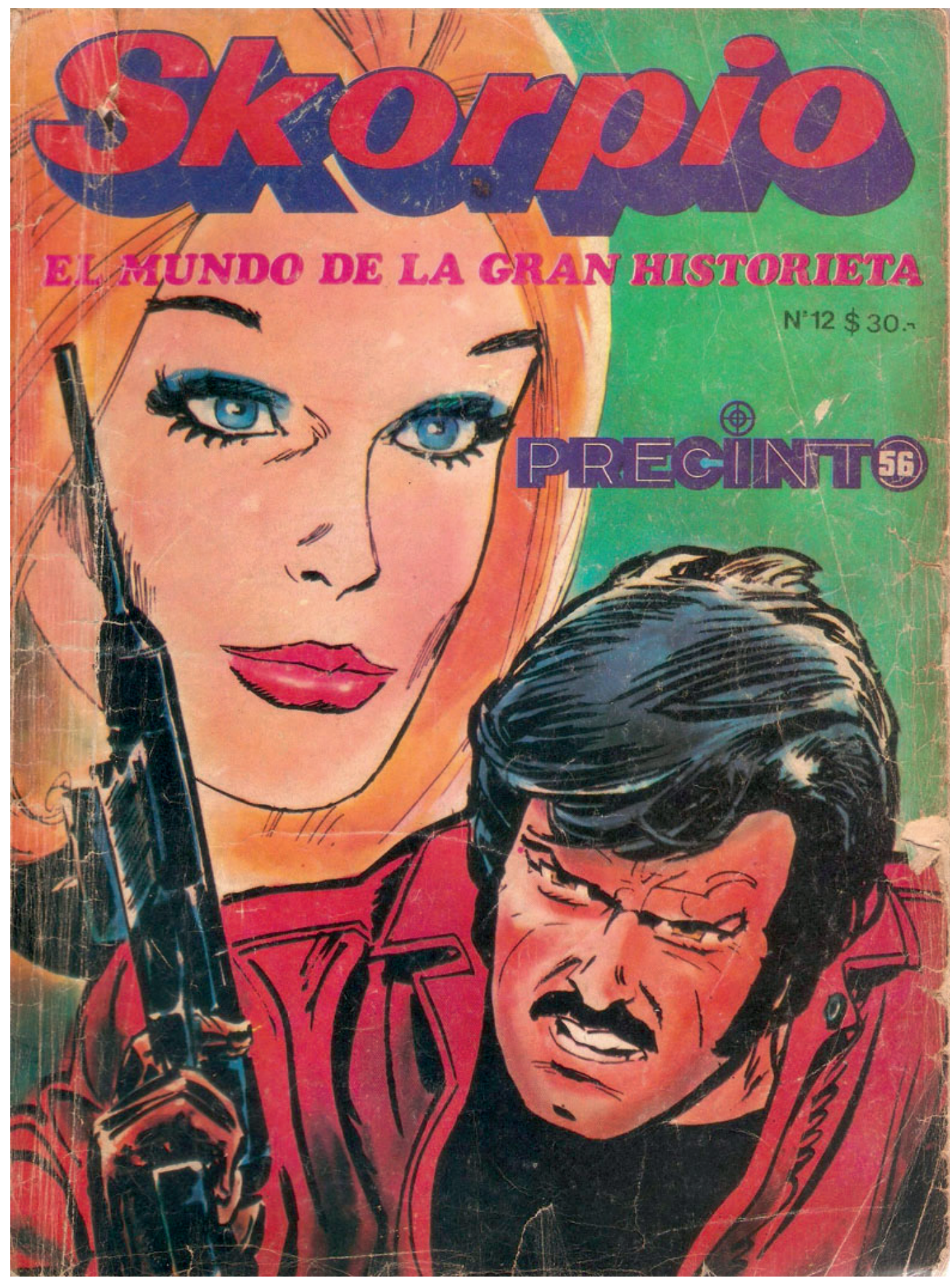

FIG. 2. Cubierta de la revista Skorpio 2. Editorial Récord, 1975. 
Los setenta son sumamente complejos y difíciles. Al principio de la década se experimentó un repunte económico que parecía revertir la curva negativa de toda la década de los sesenta que había sufrido la industria de la historieta. Esto duró hasta 1975, cuando comenzó una crisis económica que produjo fuertes cimbronazos políticos, porque uno de los objetivos declarados del Proceso de Reorganización Nacional de 1976 era estabilizar la economía bajando la inflación - tomando medidas neoliberales ya ensayadas pero resistidas, y que solo pudieron aplicarse bajo un sistema dictatorial y represivo.

Las políticas culturales de la dictadura hicieron que, por un lado, disminuyera muchísimo el volumen de las publicaciones masivas y que, por otro, se tuviera siempre temor a la espada de Damocles de la censura. En medio de eso sucedieron dos cosas importantes, donde se vieron involucrados Trillo y Altuna: la primera fue la nacionalización de la contratapa del diario Clarín a partir de 1973. Fue el primer diario argentino que decidió dejar de comprar tiras sindicadas e incluir tiras producidas por dibujantes y guionistas locales casi en su totalidad. Ahí empezaron a colaborar Trillo y Altuna en 1975 con «El loco Chávez», una especie de revisitación del costumbrismo argentino muy basado en cierto modelo de telenovela.

Otra cuestión clave fue la aparición de la revista Hum®en 1978, la única revista satírica con salida masiva durante la dictadura, que convocó a una gran cantidad de lectores que habían quedado huérfanos de publicaciones más revulsivas y que querían escapar del tedio del discurso mediático completamente homogeneizado. Ahí apareció otra obra clave: «Las puertitas del Señor López». Así que, desde dos medios bien diferentes, Trillo y Altuna supieron traficar significados más o menos alegóricos o deslizar comentarios desde la cotidianeidad del diario.

Son dos buenos representantes de esa generación de historietistas en un cierto uso político-ideológico de la historieta en contextos complicados y hostiles. Una de las cuestiones que nunca se pudo terminar de concretar fue la organización sindical de los historietistas. Los contextos represivos y el achicamiento del mercado editorial hacían que una editorial como Columba pusiera en una lista negra a aquellos que reclamaban derechos laborales —como le pasó a José Muñoz— cortándoles prácticamente toda posibilidad laboral.

Si a eso uno le suma el miedo posterior por la maquinaria exterminadora del PRN y la aceptación de los términos del trabajo for export -intermediarios incluidos-, se da cuenta que la situación estaba muy lejos de ser idílica, pero que, de alguna manera, en esos años se produjeron algunas de las mejores obras, la historieta cambió definitivamente y comenzó a cristalizarse como campo con sus cánones siempre discutibles.

Amadeo Gandolfo: Coincido con Pablo en la reconstrucción histórica de los períodos económicos de la historieta argentina. Desde 1971 hasta 1975 se produce un mini boom, que también se comprueba en el terreno del humor gráfico, con la aparición de Hortensia, Satiricón y, luego, Chaupinela y Mengano, esta última una revista bastante particular, dirigida por un comité editorial de sus propios artistas, en uno de los primeros intentos de coope- 
rativismo en la historieta argentina; este comité estaba formado por Trillo, Amengual y Bróccoli. Además, allí aparecieron algunos de los primeros episodios de «Un Tal Daneri».

A eso se suma, como bien menciona Pablo, la aparición de Skorpio y la nacionalización de la página de Clarín, un evento simbólico de enorme significación, que hizo que durante muchos años ese espacio fuese un lugar codiciado, no solo porque allí publicaban los mejores, sino también por las obvias ventajas económicas de estar en el diario de mayor tirada de Argentina - situación a la que Clarín accedería durante el PRN gracias a su alianza con los militares gobernantes y su adquisición ilegal de Papel Prensa.

En términos artísticos, los setenta también son un buen momento para el costado más humorístico/caricaturesco de la historieta argentina. La definitiva consagración de Quino, ya alejado de Mafalda, con sus grandes viñetas a página entera llenas de detalles, la aparición

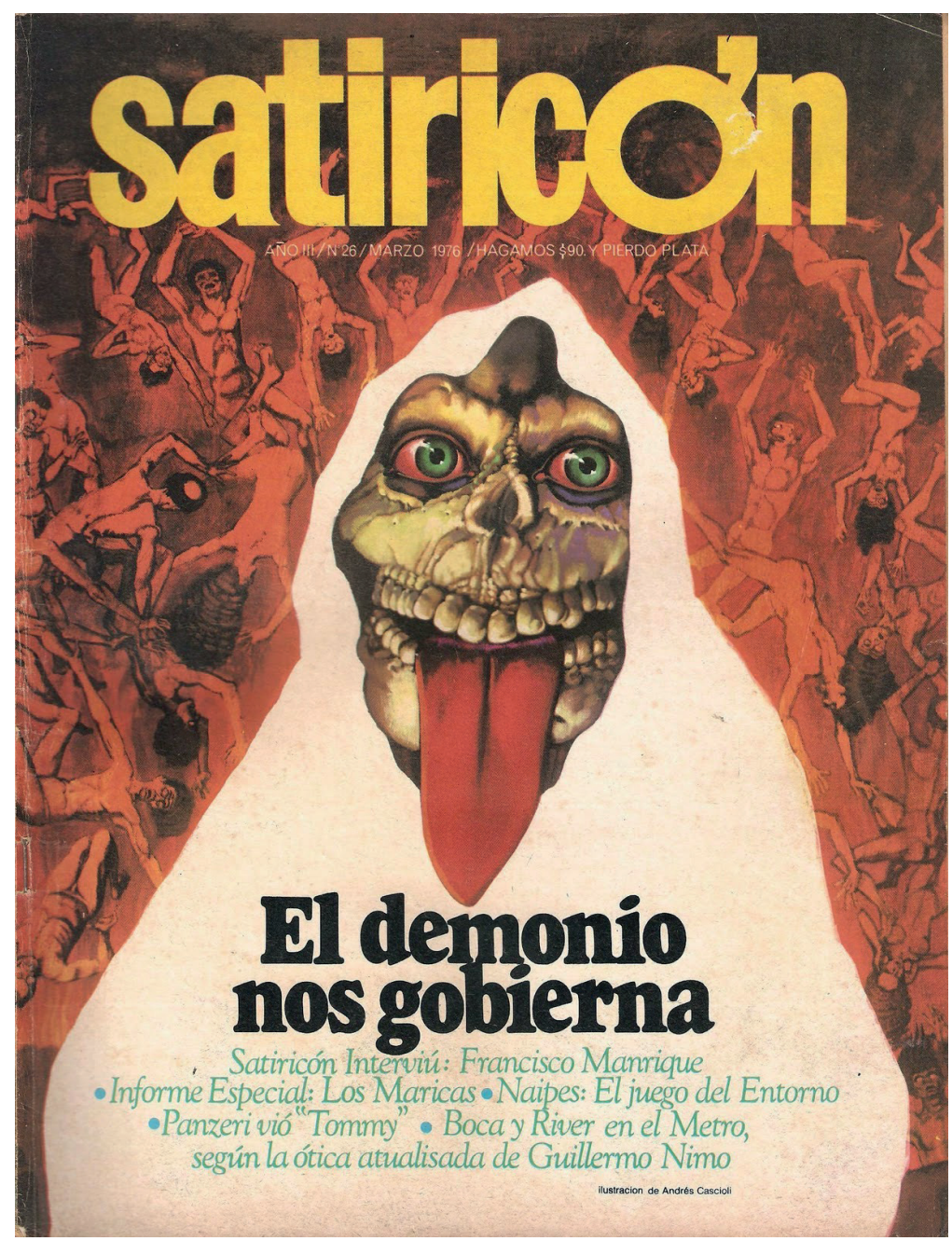

FIG. 3. VV.AA. Satiricón 26. Buenos Aires, Cascioli, Oskar y Blotta, 1976. Imagen de cubierta de Andrés Cascioli. 
de Caloi y Fontanarrosa, las primeras cosas de Tabaré, Oski haciendo algunos de sus libros más famosos y ya consagrado como gran ilustrador en Europa, al igual que Mordillo, Grondona White, Cascioli y toda la generación de Satiricón... En la primera mitad de los setenta estos autores se benefician del relajamiento de la censura con respecto al sexo y la política.

Pero, a partir de 1975-76, esa situación comienza a cambiar, primero por la crisis económica desatada por el gobierno de Isabel Martínez de Perón. En segundo lugar, como mencioné más arriba, por el crecimiento de la censura, desordenada y desperdigada en distintos niveles - municipal, provincial, nacional—, pero cada vez más omnipresente. Hasta que en 1976 hay una especie de cerrazón absoluta de las publicaciones satíricas, las cuales quedan reducidas a Hortensia en Córdoba, que se encierra, por motivos comprensibles, en un humor mucho más provinciano y costumbrista.

Pero, además, durante esta década se suceden una serie de eventos y situaciones que van estableciendo una historia retrospectiva de la historieta argentina. Por un lado, están las Bienales de Historieta en Córdoba, que comienzan en 1972 y se extienden hasta 1986, que son los primeros eventos masivos de historieta con continuidad. Las bienales hacen dos cosas: por un lado, sirven de lugar de encuentro entre historietistas, una especie de pulmón de sociabilidad en tiempos bastante oscuros. Por otro lado, comienzan una tarea de recuperación y ordenamiento del pasado, enlazando siempre el tejido de la historieta argentina con sus lectores, o sea, con la sociedad. Esto se realiza predominantemente a través de sus muestras y sus catálogos, que son verdaderos compendios de textos e imágenes de difícil acceso previo, que van construyendo un cierto canon y un cierto sentido común alrededor de los puntos altos de la historieta argentina. Recientemente estuve viéndolos y es notorio encontrar allí textos que siguen usándose hasta el día de hoy como insumos críticos: Rivera, Steimberg, Trillo y Bróccoli, gran parte de la operación de lectura de la historieta argentina que había comenzado Masotta continúa ahí.

Eso se concreta con la Historia de la Historieta Argentina, escrita por Trillo y Bróccoli y publicada por la Editorial Record de Scutti, que publicaba Skorpio. Allí los autores recopilaban algunos artículos que habían aparecido en los catálogos de las bienales y en otras revistas de la editorial y construían el sentido común histórico, marcado por la edad dorada de los cuarenta y los cincuenta y la posterior crisis.

Record y La Urraca - la editorial de Cascioli, que publicaba Hum®y, en los ochenta, Fierro- van a ser las dos protagonistas más destacadas de la década de los ochenta, con Columba siendo, con su producción masiva y grandes tiradas, una empleadora con muchos puestos, pero explotadora.

Como bien dice Pablo, la sindicalización nunca fue posible, y las organizaciones que se supone debían llevarla adelante, como la Asociación de Dibujantes de la Argentina, nunca tuvieron mucho poder de organización. Además, tuvo momentos de cierto patetismo, como, por ejemplo, la firma de una solicitada que pedía a las editoriales, durante la Guerra de las Malvinas, que supriman «historieta y todo material ilustrado cuyo contenido, directa o in- 


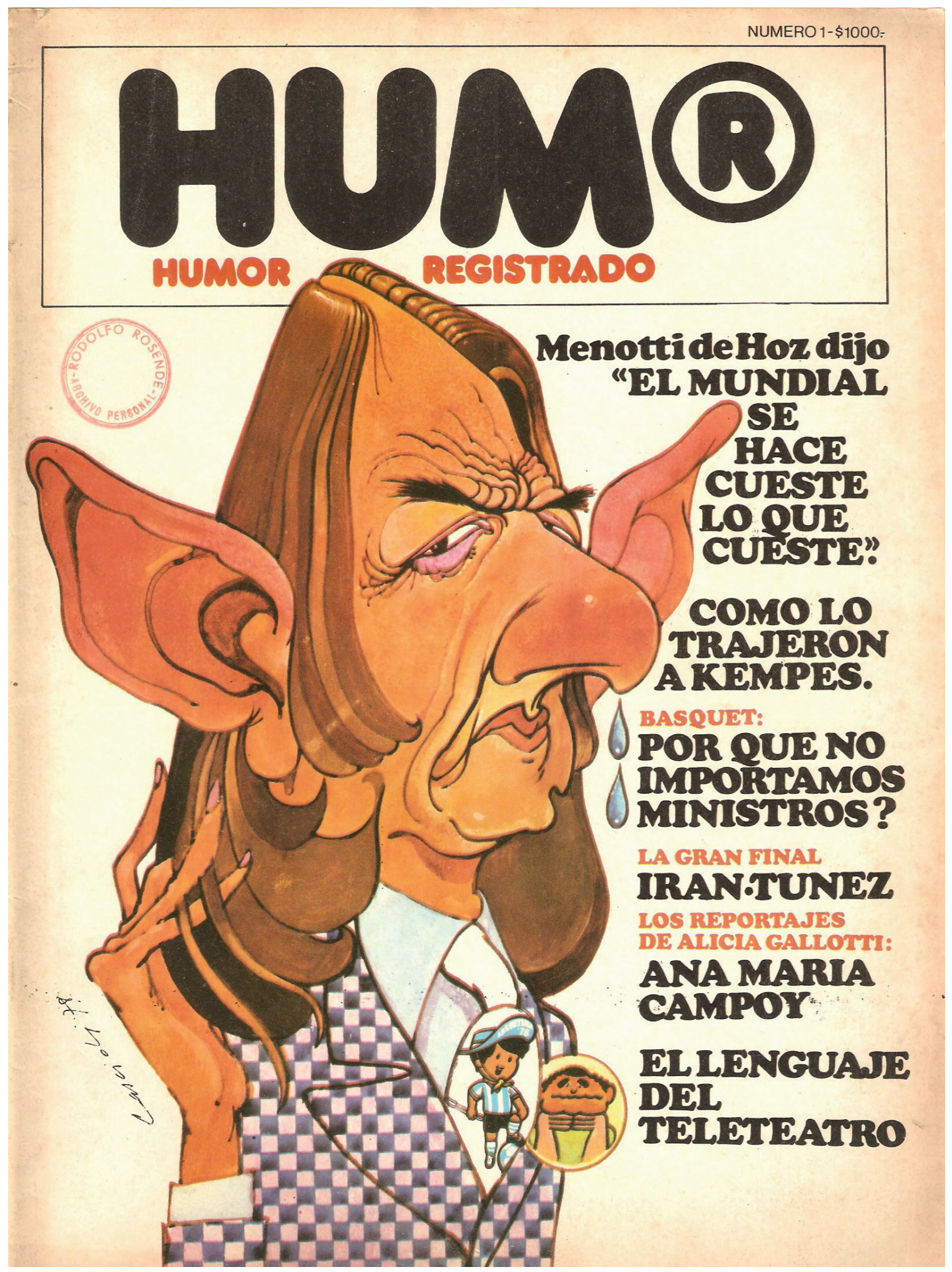

FIG. 4.VV.AA. Hum®1. Buenos Aires, La Urraca, 1978. Imagen de cubierta de Andrés Cascioli. 
directamente, sirva a los intereses colonialistas del país agresor y sus aliados». Sin embargo, y para ser sinceros, apenas fue declarada; el apoyo a la guerra y el chauvinismo eran masivos y notorios en toda la sociedad argentina.

Gerardo Vilches: Tampoco en España hubo posibilidad de sindicación o de agruparse para defender mejor los derechos de los dibujantes en esa época. Y no es el único punto en común, según lo que habéis señalado ambos: también se da esa mezcla de autores nuevos y consolidados, es un momento de cambio de paradigma en el que, como muchas corrientes llegaban con retraso al país, existe una significativa superposición de corrientes y tendencias que cristalizó, por un lado, en la configuración de una primera teoría del cómic en España y, por otro, en la aparición de ciertas polémicas de corte tanto artístico como ideológico en torno al cómic.

Sobre lo primero, la aparición de una teoría del cómic —algo que vosotros también destacáis en el caso argentino- es esencial para el desarrollo artístico de un medio, en mi opinión, no solo porque es preciso recuperar y conservar su historia, sino porque la reflexión sobre el medio y su lenguaje es una ayuda indispensable para su avance. En España habíamos tenido ya Bang!, la primera publicación teórica de la que yo tengo noticia, publicada por primera vez en 1968, bajo la dirección de dos pioneros del estudio del cómic en España: Antonio Martín y Antonio Lara. Se publicó, significativamente, hasta 1977 —aunque tan solo aparecieron quince números-, año a partir del cual comenzaron a proliferar las revistas de cómic adulto. Ese mismo año aparece Los cómics: un arte del siglo XX, de Javier Coma, un estudioso del medio muy influyente de esa etapa. También estuvo involucrado en la Historia de los Comics que publicó Toutain por fascículos a partir de 1983, una obra que muchos autores y teóricos actuales consideran un referente - y que, supongo, sería equivalente a la obra de Trillo y Bróccoli citada por Amadeo-, y a través de la cual se conocieron, por primera vez en España, muestras de muchos clásicos de prensa americanos.

Esta primera teoría más o menos consolidada tenía sus carencias, evidentemente: en muchos casos, sus impulsores eran aficionados, expertos en otros campos que, por amor al cómic, hicieron estos primeros esfuerzos legitimadores y divulgativos. Pero su labor, en muchos casos, estaba polarizada por sus filias y gustos personales. Estaban quienes consideraban el cómic norteamericano de prensa de dibujo realista de la edad dorada la cima del medio, y también los fanáticos de la línea clara, «francófilos» que veían en Hergé el culmen del cómic internacional. Existió, hasta cierto punto y siempre teniendo en cuenta que hablamos de un mundo muy pequeño, una batalla por la hegemonía, por definir qué era el cómic adulto y marginar aquello que no convenía, en esos momentos, a los diferentes discursos sobre la calidad artística del medio. Esa batalla tuvo un momento clave en la polémica en torno a una exposición sobre Hergé en la Fundación Miró de Barcelona, en medio de la cual un grupo de autores e intelectuales —entre los que estaban Javier Coma, Josep Toutain o Víctor Mora- emitió un manifiesto ${ }^{1}$ en el que expresaban su preocupación por la imagen infantil

${ }^{1}$ Delclós, T. «Manifiesto contra una exposición de “Tintín”y Hergé», en El País (14 de septiembre de 1984). Disponible en: https://elpais.com/diario/1984/09/14/cultura/463960802 850215.html 

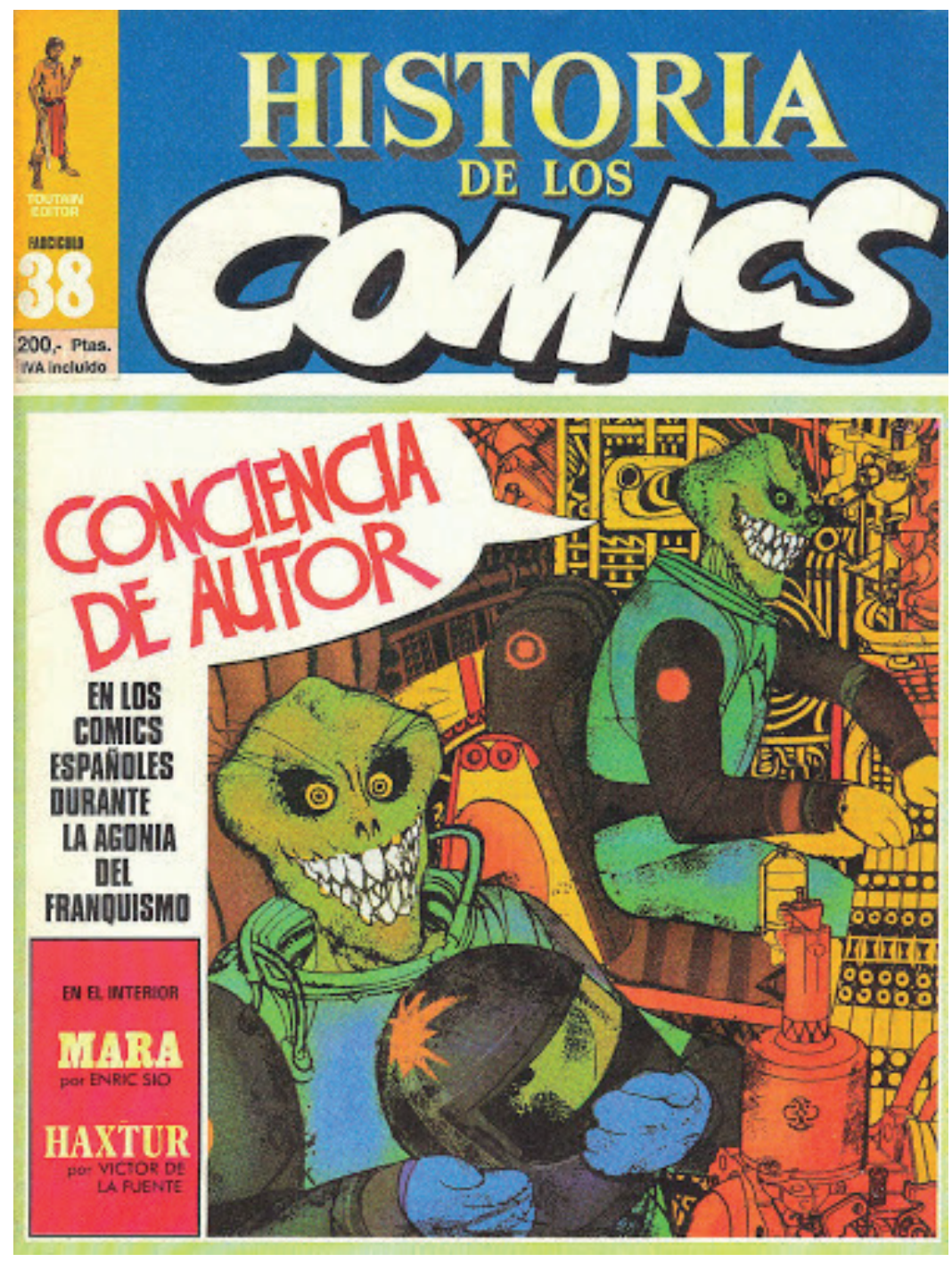

FIG. 5. Coma, J. La historia de los cómics. Barcelona, Toutain Editorial, 1982.

que daba del medio esa exposición en un momento en el que, en España, se estaba trabajando para asentar el cómic como una forma de expresión artística y adulta... Como si Terry y los piratas o cualquier otra de las series admiradas por ese grupo fueran mucho más adultas que Tintin. Eran cosas de la época, pero es significativo porque ese debate más o menos enconado se trasladó a las revistas, cuyos editoriales y artículos giraban a menudo en torno a estos enfrentamientos, con ataques a la acera de enfrente incluidos. En cierto sentido, ser comprador en los primeros ochenta de tal o cual revista implicaba una «militancia» de una manera de entender el cómic, aunque, por supuesto, mucha gente compraba y leía de todo. Fue, más bien, algo iniciado y alimentado por editores y críticos.

En cuanto al tipo de publicación que se podía encontrar en estos años álgidos del boom del cómic adulto en España, existió cierta variedad. Para empezar, porque los quioscos estaban satu- 
rados de material. Aunque hablamos de pocas editoriales — principalmente, Toutain y Norma Editorial-, se lanzaban constantemente nuevas revistas para competir con el rival y copar el espacio de exposición al público, aunque no hubiera, en muchos casos, un público suficientemente amplio como para absorber semejante oferta. La repetición de contenidos, la sobreexplotación de autores - caso paradigmático fue el de Richard Corben por parte de las revistas de Toutain- y la recuperación de material de cierta antigüedad eran habituales. Pero también apareció una nueva práctica: la publicación en álbum de las historias más populares, una vez había finalizado su serialización en una revista, tanto de material extranjero como nacional.

Por centrarnos en las revistas concretas, junto a las que ya mencioné de finales de los setenta aparecen Creepy (1979) o Metal Hurlant (1981), cabeceras que, de un modo u otro, continúan con las mismas corrientes de publicación de material de género francobelga y estadounidense, de ciencia ficción y terror. Rambla (1982) fue un proyecto de Carlos Giménez, Luis García, Alfonso Font, Josep María Beá y Adolfo Usero. Es decir: la generación, ya madura, que empezó a publicar en Selecciones Ilustradas y protagonizó la primera oleada de cómic de autor. En la revista se publicaba mayoritariamente material autóctono; básicamente, el producido por sus impulsores y autores afines.

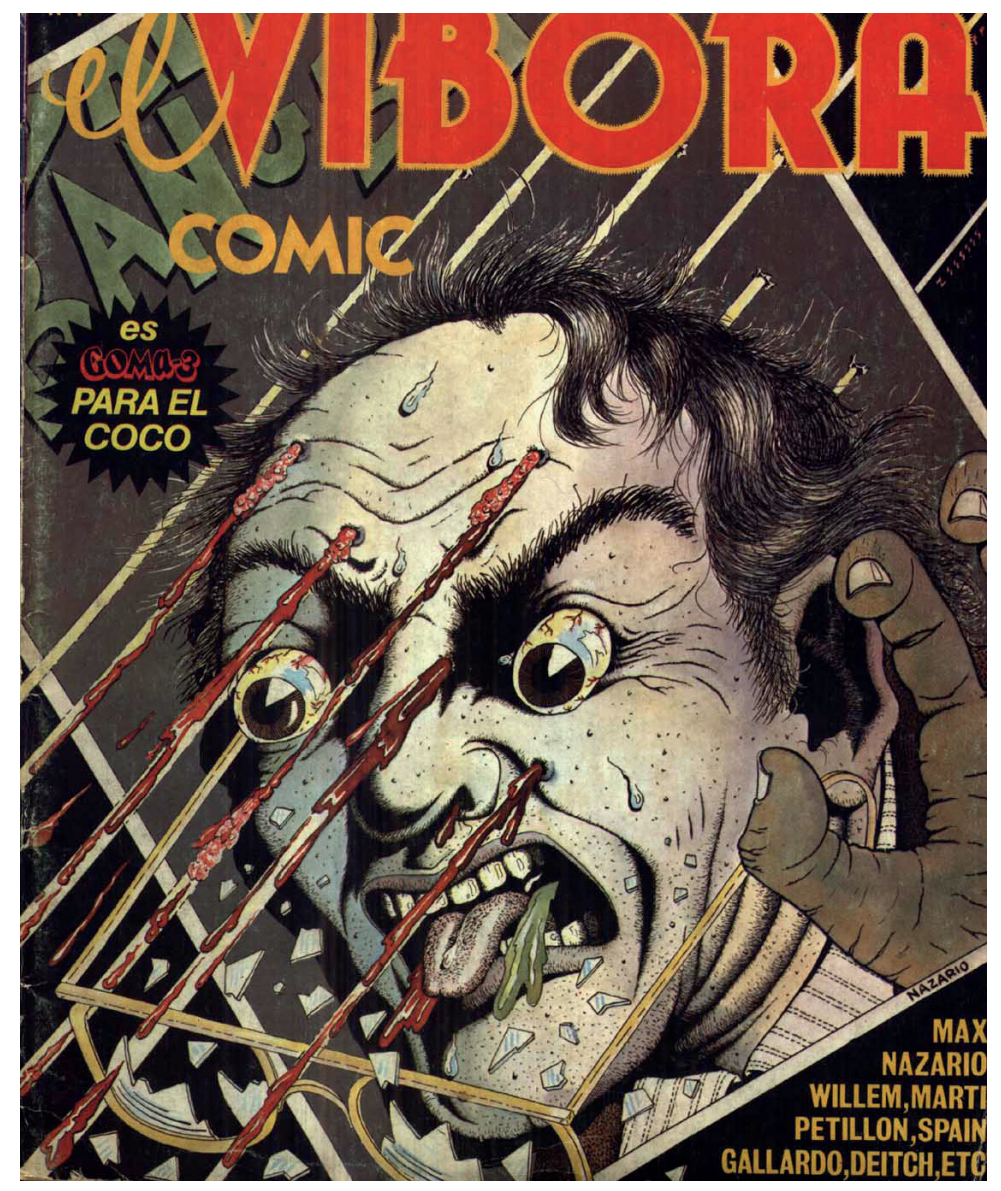

FIG. 6. VV.AA. El Víbora 1. Barcelona, La Cúpula, 1979. Imagen de cubierta de Nazario. 
Pero las dos revistas más novedosas fueron El Víbora (1979) y Cairo (1981). La primera fue una iniciativa de Josep Maria Berenguer, apoyado económicamente por Toutain. El Víbora aglutinó a los mejores autores del underground barcelonés — principalmente Max, Gallardo y Nazario- junto a otros como Martí o Laura Pérez Vernetti. Su intención fue dar a conocer el cómic adulto más duro, sin condicionantes de género, sin recurrir a sofisticaciones de la ciencia ficción o fantasía de siempre. Sus cómics hablaban de la calle, de drogas, delincuencia y violencia, desde un profundo desencanto, como ha dicho Pedro Pérez del Solar. ${ }^{2} \mathrm{Al}$ mismo tiempo, fue la publicación que prestó atención a la verdadera modernidad del cómic adulto, a los autores contemporáneos que estaban innovando y ofreciendo experiencias nuevas. Por sus páginas, en los primeros años, llegaron a pasar gente como Art Spiegelman, Charles Burns, Robert Crumb, Yoshihiro Tatsumi... Dibujantes, todos ellos, que no tenían lugar en las publicaciones más ortodoxas y constreñidas.

En cuanto a Cairo, publicada por Norma y dirigida por Joan Navarro, fue la máxima representante en España de la línea clara. Navarro esgrimió desde los primeros números un discurso que hoy podríamos ver como reaccionario, que reivindicaba la pureza del tebeo de toda la vida, de la aventura y el humor blanco. Acunó el término de «neotebeo» para definir Cairo y buscó publicar historietas que, partiendo de los presupuestos estéticos de la línea clara definida por Joost Swarte, actualizara las fórmulas del tebeo de aventuras para un público moderno. Lo hizo contraponiéndolo explícitamente a la línea editorial de El Víbora, que se consideraba, desde los textos publicados en Cairo, de mal gusto. En Cairo publicó una nueva generación de autores, muchos de ellos adscritos a la denominada Nueva Escuela Valenciana, que habían estado publicando en el ámbito local desde los setenta: Sento Llobel, Daniel Torres, Mique Beltrán...

Por último, hay que destacar la experiencia de Madriz (1984), una revista subvencionada por el ayuntamiento de Madrid y dirigida por el guionista Felipe Hernández Cava, en la que tuvieron cabida las corrientes más vanguardistas y rupturistas del momento. Fue una revista innovadora, con frecuencia atacada e incomprendida por los aficionados y teóricos más clásicos, y que se inserta en la estética de la movida madrileña. Por sus páginas pasaron Ana Juan, Ana Miralles, Federico del Barrio, OPS, Rubén e incluso jóvenes autores que hoy son referentes de la novela gráfica, como Javier Olivares y Juan Berrio.

Como ya apunté, esta situación, este boom, no se sustentaba en un público lo suficientemente amplio como para que fuera sostenible más allá de unos años. Las editoriales se lanzaron en una carrera por ver quién publicaba más revistas, con la esperanza de ahogar a la competencia, y los títulos se sucedían sin pausa. Se cerraban cuando arrojaban pérdidas o se relanzaban con otros nombres. Pero la bonanza para el lector duró tan solo unos pocos años. Madriz cerró en 1987; la primera etapa de Cairo, en 1984; Rambla, en 1985; la primera época de Totem y Comix Internacional, en 1986; Creepy, en 1985. Por no hablar de cabeceras menores, con una duración efímera. Para cuando llegamos a los años noventa, el panorama ha quedado muy reducido. Pero no quiero adelantar acontecimientos.

2 Pérez del Solar, P. Imágenes del desencanto. Nueva historieta española 1980-1986. Madrid, Iberoamericana-Vervuet, 2013. 
Historia de dos industrias: un debate en torno a la historieta argentina y española II

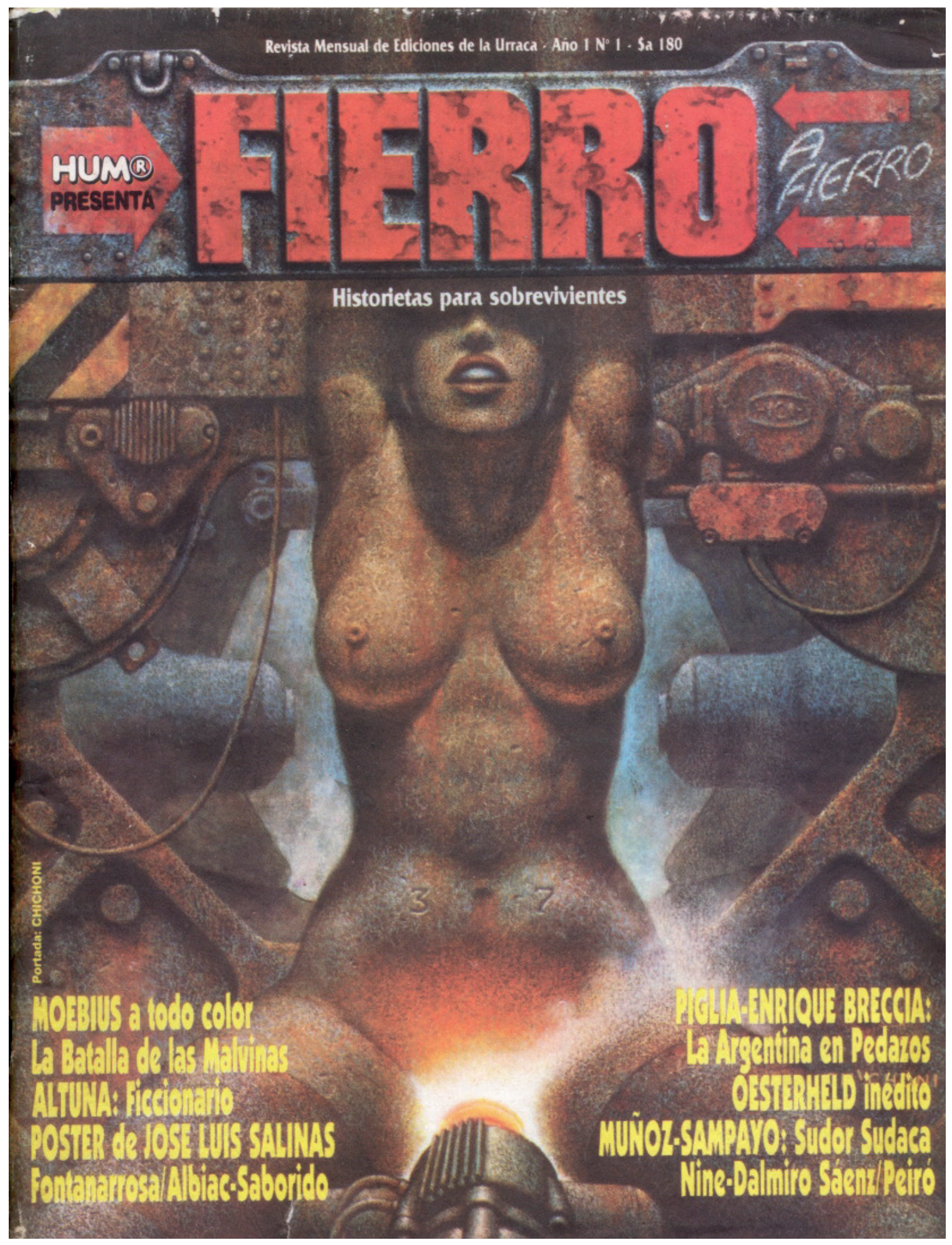

FIG. 7. VV.AA. Fierro 1. Buenos Aires, La Urraca, 1984. Imagen de cubierta de Óscar Chicioni. 
Amadeo Gandolfo: Lo que contás, Gerardo, es bastante similar a lo que acontece en Argentina en los ochenta. Como hemos mencionado arriba, está muy marcado por las revistas de La Urraca, primero Superhumor, hasta 1984, luego Fierro, hasta 1992. Fierro en particular tiene el aura de lo sagrado y lo importante, de la última gran revista de antología argentina. No por nada se encuentra en estos momentos en su tercera encarnación y su nombre se niega a morir. Esta revista publica gran parte de la producción de los autores argentinos que emergían consagrados de los setenta: Trillo, Mandrafina, Altuna, Muñoz, Sampayo, Sasturain, Juan Giménez, Fontanarrosa, Breccia — ya una leyenda viviente-, Solano López. Por otro lado, seguía republicando a Pratt, a Moebius y, en general, a la generación europea de los sesenta y setenta. Sin embargo, hacia la mitad de su existencia, con Sasturain alejado de la edición de la revista, comenzará a alimentarse de nuevos dibujantes: Max Cachimba, Podetti, Risso, El Marinero Turco, etc., que introducirán nuevos estilos, en algunos casos bastante alejados de la representación «realista» y la historieta de aventuras. Pero este punto central es justamente neurálgico porque muchas de las iniciativas iniciadas en este período -Tiras de Cuero, Feriado Nacional, Puertitas, etc.— van a durar pocos números.

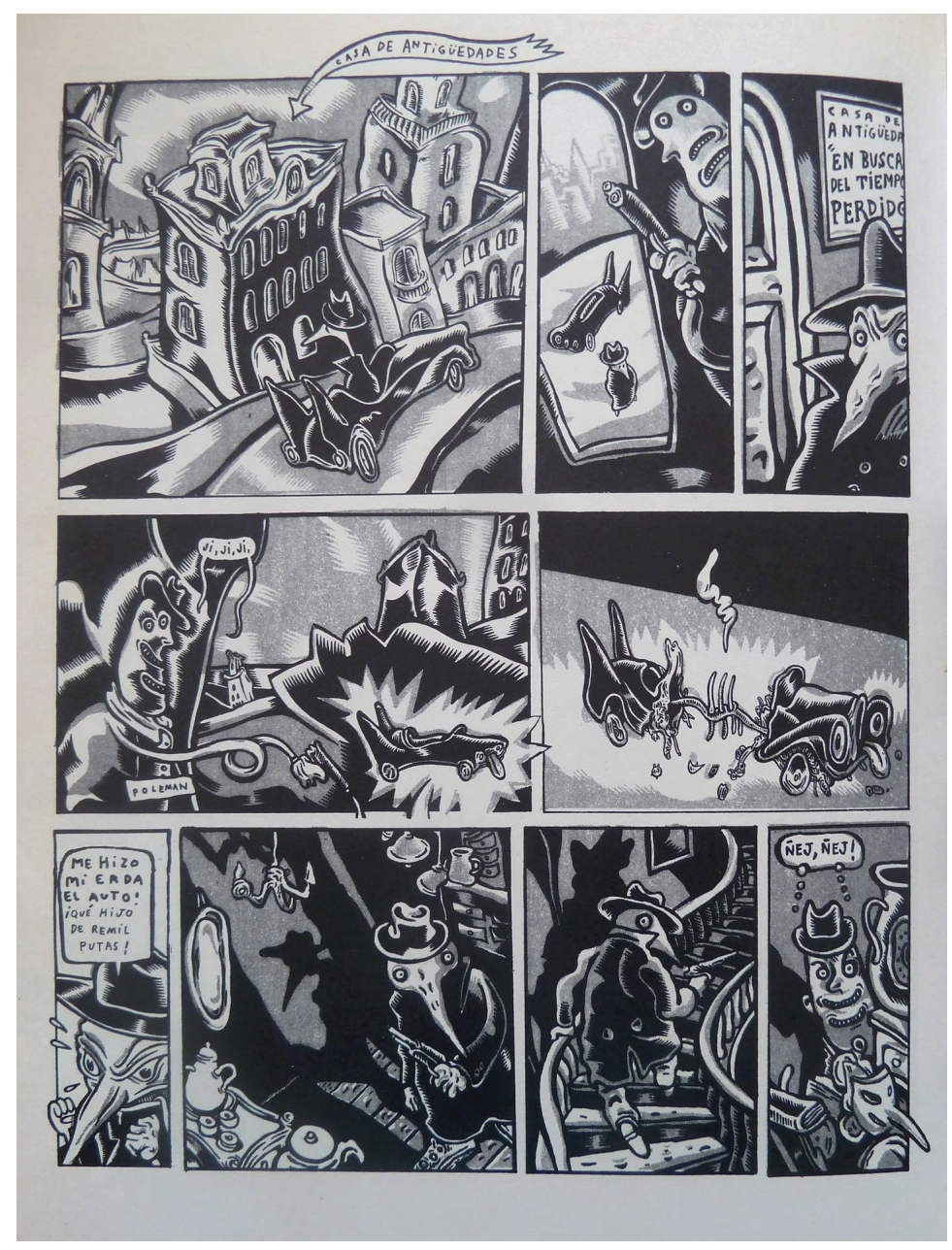

FIG. 8. De Santis, P. y Max Cachimba. «E1 último espía», en Fierro (circa 1988). 
Con respecto a lo que mencionás sobre la operación crítica sobre la historieta, al menos para mí y para varios dibujantes y lectores un poco más grandes que yo, la Historia del Comic de Coma fue una piedra angular en nuestra formación. En primer lugar, por su reproducción de muchísimas historietas que no se habían visto antes en Argentina - o se habían visto en fetas y de manera desordenada-, fue importante para tomar contacto con la producción de un Crumb, un Corben. Por otro, porque era realmente abarcadora, y fue una de las primeras historias del cómic en donde Argentina tenía un papel importante. Los debates, un poco, se nos pasaban por alto, más allá de la insistencia de Coma y compañía en la figura del autor, que habían adoptado del discurso cinematográfico, y en la preocupación por la madurez. La colección se publicó acá íntegra, pero muchos accedieron a ella más tarde, a través de casas de revistas usadas, especialmente en las provincias, con lo cual su labor pedagógica se extendió en el tiempo.

Por otro lado, a mitad de los ochenta comienza a salir un fanzine que va a tener un papel fundamental durante todos los noventa, ya convertido en revista especializada: Comiqueando. El producto a pulmón de dos hermanos, Andrés y Diego Accorsi, Comiqueando en prin-

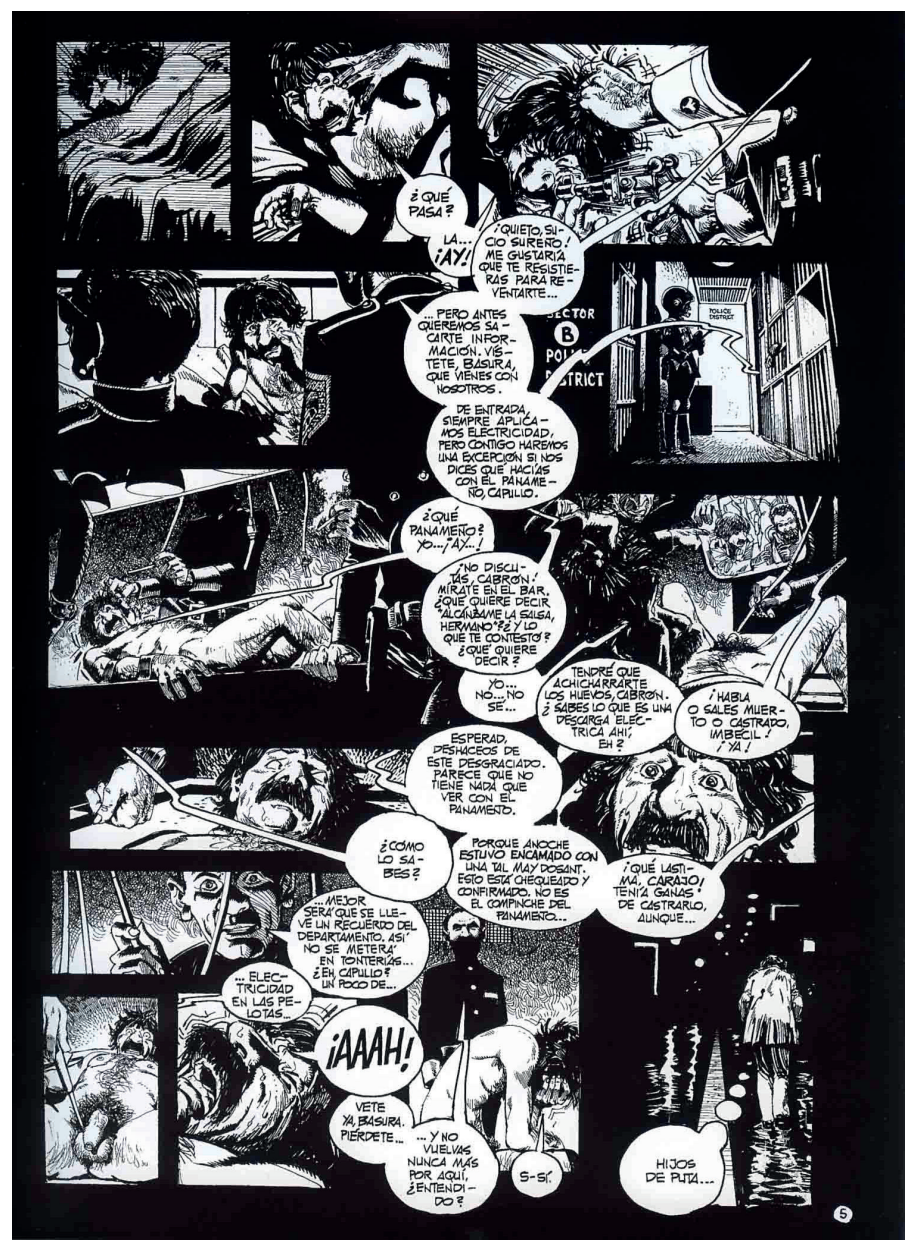

FIG. 9. Altuna, H. «Ficcionario», en 198450 a 62 (1983). 
cipio era un pasquín fotocopiado que, a la preocupación por lo europeo y nacional, agregaba el interés por los superhéroes de Estados Unidos, que en Argentina se habían consumido mayoritariamente en ediciones de la mexicana Novaro, en donde abundaban las historias incompletas y los números salteados producto de las dificultades de distribución.

Las nuevas vibras de Fierro y la aparición de Comiqueando señalan los elementos que van a ser importantes en la década subsiguiente: una generación de autores a caballo entre Europa y el underground norteamericano, el formato fanzine, la autoedición como camino. Porque a pesar de que es una etapa con una producción muy diversa y rica, los ochenta en Argentina y el periplo de La Urraca son como el último coletazo de algo que se venía muriendo, al menos, desde mitad de los sesenta. Las ventas ya no eran espectaculares y el formato de antología pronto iba a sufrir su crisis terminal en Europa, que se iba a replicar en Argentina.

Los ochenta en la historieta argentina son muy ponderados en el recuerdo, como una etapa de grandes obras, apertura estilística y enorme libertad temática, producto del final del PRN en 1983 y el retorno de la democracia, una democracia de la cual estas obras son en gran medida hijas. Eso también se refleja en la manera en que las historietas «de autor para adultos» tratan el tema de la dictadura en los ochenta: con ansiedad, con una simbología transparente, con un buen grado de denuncia. Algo similar a lo que pasaba en el cine, ejemplificado en La Historia Oficial y su triunfo en los Oscar. Pero como siempre dice Pablo: después de tanto tiempo hablando con sordina o no diciendo nada, era la única manera de lidiar con ello.

Pablo Turnes: Antes que nada, déjenme decir que para mí La Historia de los Cómics fue de un valor incalculable, una verdadera escuela estética. Nunca lo tuve completo, pero cada número que tenía me parecía increíble, el diseño era hermoso. Una especie de aventura enciclopédica maravillosa, de esas que uno tiene cuando es chico y después nunca más, al menos con ese grado de sorpresa y felicidad.

A mediados de la década de 1980, comenzó la crisis de la historieta de autor europeo. Había durado unos veinte años, con una hipérbole en los setenta, y después se fue en picado. En Estados Unidos pasó algo similar, ¿no? Se producen clásicos, pero no necesariamente era el mejor momento a nivel de ventas. Hay algo ahí que cambia, no sabría decir exactamente por qué, pero coincide con la entrada del anime a Occidente. No digo que la industria japonesa debilitara a las industrias nacionales; yo creo que la manera de pensar la historieta se había anquilosado y ya no le hablaba a un público como el que pensaba o quería tener. El manga/ anime ofreció una opción para mucha gente que la historieta más tradicional ya no podía ofrecer.

La retracción del mercado europeo hizo crujir el mercado local. A todo esto, hay que sumarle la crisis económica hiperinflacionaria de 1989 y las medidas de corte neoliberal, como la apertura del mercado y la desindustrialización. Entonces, tenés un cóctel explosivo porque el desgaste de una manera de contar y una dependencia con Europa se mezclan con medidas políticas que perjudican la competencia y, por lo tanto, dificultan sostener tiradas masivas. 
Las revistas, más o menos, aguantaron la primera mitad de los noventa, pero para la segunda mitad el crack fue rápido y evidente. En esa liberación de fuerzas de la historieta, se dan varias respuestas que podemos sintetizar en dos: una quería seguir un camino profesional, aunque para eso ahora tuviera que autoeditarse (jSuélteme!, El Lápiz Japonés); la otra se expresó en los fanzines, donde la autoedición era la condición sine qua non de esa movida.
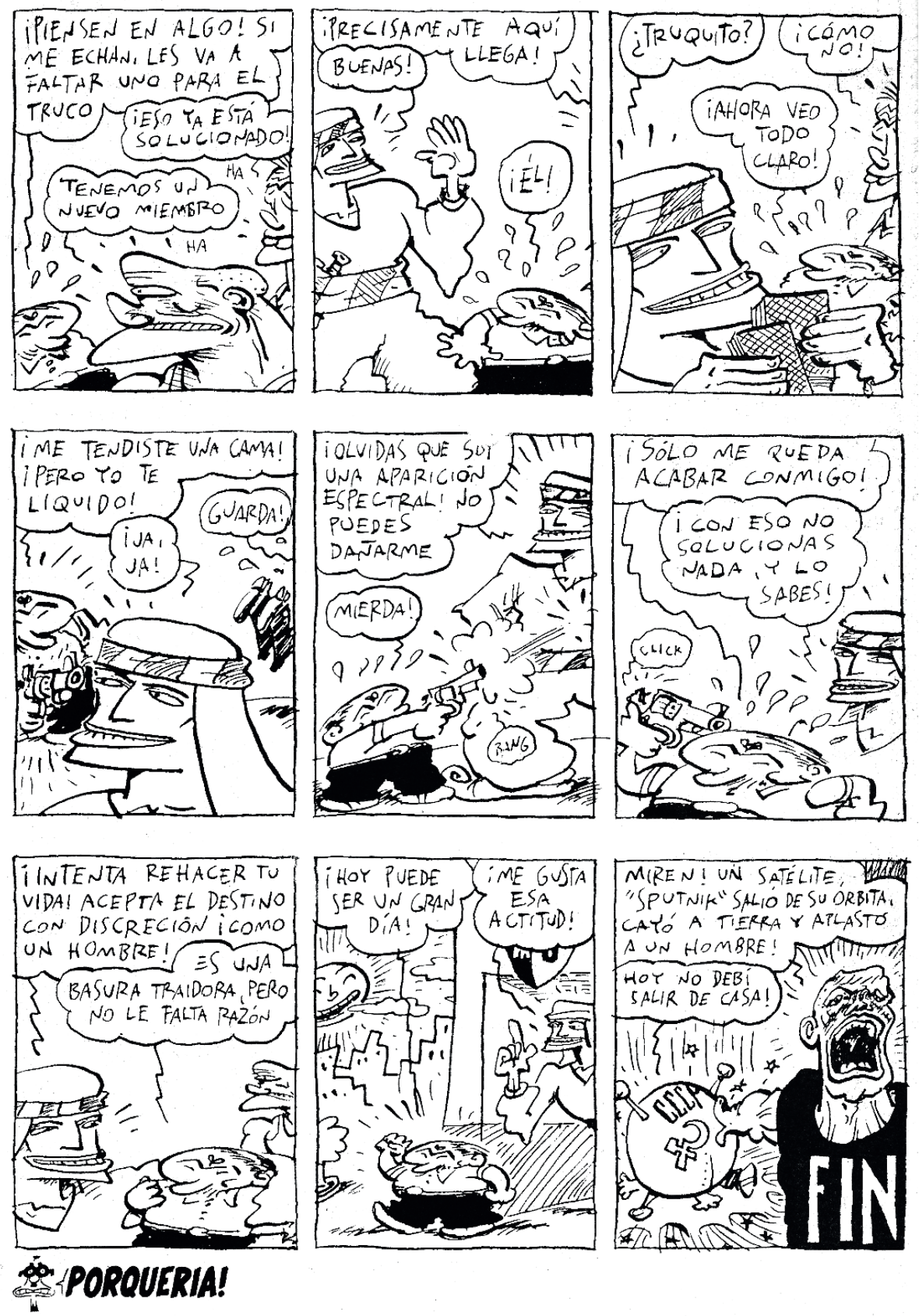

FIG. 10. Fayó, P. «Porquería», en Suélteme 4. Argentina, 1997. 
Esto no significa que fueran todos iguales y que todos tuvieran los mismos objetivos. Había gente que quería mostrarse para ser publicada y otra que tomaba seriamente la idea de independencia creativa, pero que no por eso dejaba de lado el diseño y una aproximación lo más profesional posible a lo que se hiciera. Creo que ejemplos como Catzole y Kapop serían de este tipo. Lo que se compartía era ese principio de querer expresarse y tener derecho a eso, con mejores o peores resultados, pero, en conjunto, colectivamente.

Por supuesto, había peleas y dramas internos - Diego Agrimbau lo recuerda con mucha gracia y precisión - ${ }^{3}$ pero durante esos años de crisis económica y social la idea de la cultura compartida fue una red y un sostén que nos sirvió para mantenernos vivos. Y se expresó así en el mundo de la historieta posindustrial, hasta que internet cambió bastante las reglas del juego. Sin embargo, sigue habiendo eventos y son claves, eso habla de cómo la institucionalización de esos espacios lleva ya veinte años o más. La idea de que internet des-socializa no es falsa, pero tampoco es absoluta: al contacto frecuente, regular y esperado que ofrecen los eventos, se le sumaron las redes sociales para hacer de promoción e información.

No puedo ofrecer números concretos, solo es una sensación, pero creo que en los últimos años la historieta ha ganado público no solo en cantidad, sino en diversidad. Eso no era tan así en los noventa, pero al mismo tiempo fue en ese momento donde se sentaron las bases para lo que iba a venir. La pregunta es: ¿por qué la historieta? Tenía buenas chances de desaparecer para siempre, y, sin embargo, es como la Hidra de Lerna: le cortaron una cabeza y le salieron veinte. Evidentemente, hay algo resistente y hasta primitivo en ese lenguaje, algo que permite refugiarse y comunicarse de una manera muy particular con los otros. $Y$ es un circuito, además, donde dinero hay poco y donde ese lenguaje difícilmente es objeto de vigilancia por autoridad alguna - la cual, a su vez, tampoco hace mucho por la historieta en general-. Yo creo que por ahora, al menos, hay más libertad que en otros lugares de la cultura. Podrá ser precario, pero funciona.

Gerardo Vilches: Me resulta muy interesante vuestra descripción del crack de la industria argentina, porque creo que pueden establecerse paralelismos claros con el caso español, a pesar de las divergencias lógicas. Como os comentaba, en España, la escena de las revistas de cómic adulto llega a los años noventa muy diezmada. Como decís, las causas para este declive son muchas; es un error, a mi juicio, buscar explicaciones reduccionistas o unicausales. Para mí, es muy importante entender que el ocio se orienta, durante los años ochenta, a otros medios, principalmente los videojuegos y la televisión - a principios de los años noventa inician su emisión las primeras cadenas privadas, ampliando la oferta televisiva-. Pero, además, hay que tener en cuenta los propios errores cometidos por la industria del cómic español: en lugar de mantener y cuidar una o dos cabeceras, las editoriales lanzaron una tras otra, con el fin de asfixiar a la competencia y copar el espacio de exposición en los quioscos. Faltó también una renovación estética, y se abusó de determinado tipo de material

${ }^{3}$ Gandolfo, A. y Turnes, P. «La historieta es una herida absurda. Entrevista con Diego Agrimbau (1. ${ }^{\text {a }}$ parte)», en Kamandi (28 de julio de 2017). Disponible en: http://www.revistakamandi.com/2017/07/28/ la-historieta-es-una-herida-absurda-entrevista-con-diego-agrimbau-1ra-parte/ 
en exceso. El hecho de que los lectores percibieran que en las revistas había solo una parte que les interesaba también los alejó de las mismas: tarde o temprano, el material popular era recopilado en álbumes, que fueron preferidos por muchos. El emporio Bruguera, que había declarado una suspensión de pagos en 1982, vio cómo Ediciones B adquiría su fondo e intentaba reconstruir su universo de publicaciones infantiles y juveniles en 1986, pero no pudo evitar el declive a lo largo de la década siguiente, como tampoco fueron capaces los grandes editores de revistas adultas: Norma Editorial y Toutain. Las únicas revistas que sobreviven al cambio de milenio son El Jueves, orientada al humor, y El Vibora, que terminará cerrando en 2004. A ellas habría que sumar la autogestionada TMEO.

También creo que es importante señalar la competencia que dentro del propio cómic tuvieron estas revistas, y, en concreto, la producción española. Pablo ha señalado, en el caso argentino, la competencia del manga; en España, antes que este suponen una competencia significativa las series de Marvel, que a partir de 1983 serían publicadas por Cómics Forum, un sello de Planeta de Agostini. Por supuesto, hacía años que los superhéroes americanos estaban presentes en el mercado español, como vimos; inmediatamente antes que Forum, Vértice, Bruguera y Surco habían sido las detentadoras de los derechos de Marvel, pero sus publicaciones eran caóticas y de escasa calidad: malas traducciones, pésima reproducción de materiales, manipulación de los mismos... Hasta la llegada de Cómics Forum, ser coleccionista era toda una aventura. Forum respetó el orden cronológico de las series, acreditó a los autores y publicó en un formato un poco más grande que el comic book, pero muy similar. Series como Spiderman, Conan el bárbaro o La Patrulla-X, que se contaron entre sus primeros lanzamientos, se convirtieron en superventas, y el número de series en el quiosco se multiplicó exponencialmente, a medida que se afianzaba en el mercado esta propuesta, que gozó de gran aceptación entre el público. Incluso hoy, se sigue hablando de «generación Forum» para referirse a los aficionados que se iniciaron en el medio gracias a esas publicaciones a principios de los años ochenta. Esta oferta se ampliaría con la llegada de Ediciones Zinco, que logró los derechos de DC Comics, y, más adelante, con la propia Planeta, que lanzaría un sello nuevo, World Comics — tras el que estaban, en realidad, los mismos responsables de Forum-, que traería a España series de editoriales como Image, Malibu, Crossgen, etc. Norma Editorial, por su parte, se encargaría de publicar el material de Dark Horse y, posteriormente, del sello Vertigo de DC Comics.

A esto hay que sumarle el primer boom del manga en España, que llega, por lo que habéis comentado, un poco más tarde que en Argentina: concretamente, en 1992 aparece la primera edición de Dragon Ball de Akira Toriyama, publicada por Planeta de Agostini, que obtuvo un éxito sin precedentes. Planeta y otras editoriales intentaron aprovechar su tirón con otras series de shōnen y shöjo, pero muchas de ellas quedaron inconclusas porque este primer boom evidenció ser, en cierta medida, ilusorio, en tanto que se cimentaba en el éxito abrumador de Dragon Ball y en el anime que también había empezado a llegar, tanto en televisión como en el mercado de vídeo. Estos mangas, además, se publicaban en un formato que imitaba al comic book, algo en absoluto adecuado para su ritmo narrativo. No será hasta finales de la década de los noventa cuando Glénat - la división española del gigante editorial francés - logre implantar el formato de tomo en España, que el manga asentará definitivamente. 


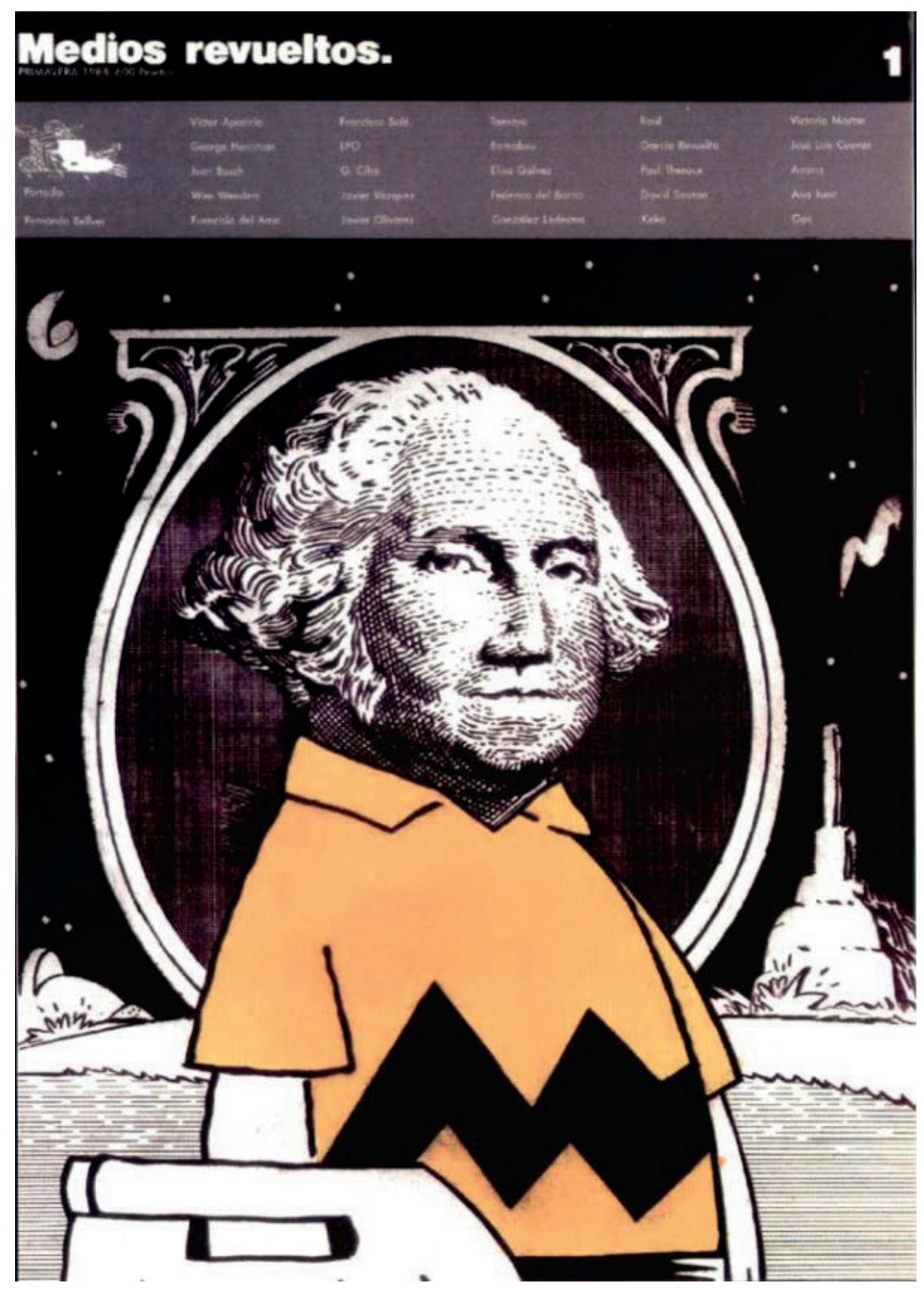

FIG. 11. VV.AA. Medios revueltos 1. Madrid, ACMR, 1988.

Con este panorama, no resulta difícil imaginar que los autores españoles quedaron en una situación muy comprometida: con cada vez menos revistas en las que publicar sus series, muchos de ellos comenzaron a publicar en Francia o Estados Unidos, u orientaron su actividad a otros campos profesionales. Como en Argentina, pervivieron un par de revistas profesionales, ya mencionadas, pero también aparecieron otras con una intención más minoritaria, con frecuencia autogestionadas. Fue el caso de Medios revueltos (1988-1990), realizada por el mismo equipo responsable de Madriz tras el fin de esta, El ojo clínico (1996-1997) o 
el fanzine Paté de marrano (1995-1997) y su sucesor, Cretino (1997-2010). A esto hay que sumarle los esfuerzos de editoriales, como Camaleón, que intentaron utilizar el formato de comic book para publicar a jóvenes autores españoles, o los de la editorial La Cúpula — responsable de la edición de la plana mayor del cómic alternativo norteamericano en España-, que en su colección Brut Comix publicó varias series de autores españoles. Pero, en líneas generales, el panorama era complicado, y muchos autores que vivieron aquella época aseguran que se vivía con pesimismo, con la certeza, incluso, de que aquello había terminado y la única alternativa era publicar en el extranjero.

Me gustaría que nos detuviéramos un tanto en los procesos de reconstrucción de ambas industrias tras sus respectivos cracks, hasta llegar a la situación actual que describía Pablo en su última intervención.

Pablo Turnes: Antes de eso, quiero aclarar algo: en Argentina, primero se conoció el anime en los ochenta, con series como Mazinger Z, Heidi y Robotech (Macross). El manga comenzó a llegar en los noventa de la mano de las ediciones españolas, como las de Dragon Ball $Z$, y también con ediciones locales de Ivrea, como Ranma 1/2. Lo mismo pasaba con los superhéroes: llegaban los saldos de España con lo editado por Zinco y Forum, junto con las importaciones que venían directamente de Estados Unidos y las ediciones locales de títulos de DC a manos de la Editorial Perfil — nosotros tenemos nuestra generación Perfil, de la que fuimos parte- Cuando en la segunda mitad de los noventa comenzaron a sentirse los cimbronazos que anunciaban la crisis de la utopía neoliberal, se redujeron las importaciones españolas y norteamericanas; en 1995 se cortó abruptamente el plan editorial de Perfil y comenzaron a llegar las ediciones mexicanas de Editorial Vid. Cuando estas ediciones también cortaron su flujo, apareció Planeta DeAgostini, y así hasta el día de hoy, con editoriales como Ovni Press, que edita títulos norteamericanos en competencia con los tomos de Salvat y algún que otro efímero proyecto local.

Pero a lo que voy es que, mientras para el género de superhéroes o el manga uno tenía al menos dos opciones editoriales distintas — entre diferentes países que exportaban su material y las ediciones locales-, las revistas clásicas de historieta argentina desaparecían una atrás de otra: Fierro en 1992, Skorpio en 1996, Columba quiebra definitivamente en 2001, pero al menos desde 1998 solo republicaba material viejo, ya no podía pagar producciones nuevas. La retracción del mercado local es acelerado y trae como consecuencia un quiebre en la tradición historietística, porque pasa a haber una generación que lee más a Toriyama o a Grant Morrison — por poner dos ejemplos- que a Trillo y a los Breccia. Y, sin embargo, es historieta que se sigue produciendo desde Argentina, aunque con esa mezcla rara que siempre tenemos, de todo un poco: lo local mezclado con Norteamérica, Asia, Europa...

Ahora bien, para saber qué pasó después ya tenemos que hacer un recorte temporal distinto que llega hasta hoy. De hecho, creo que si ya podemos revisar esto como un ciclo es porque toda esa experiencia de los noventa, de alguna manera, cristalizó en cierta institucionalización y, al mismo tiempo, abrió paso a un periodo nuevo por el que estamos atravesando. Es decir, somos el búho de Minerva: podemos explicar las cosas cuando estas han terminado. 
Yo propongo el año 2005 como bisagra, cuando aparece el blog Historietas Reales. Aquí comienza una dinámica que implica encontrar en internet una herramienta clave para la producción de la historieta de ahí en más. En noviembre de 2006 vuelve a ser publicada la revista Fierro de manera mensual, comienzan a armarse y gestionarse espacios donde conviven talleres, artesanías, eventos musicales, feria de fanzines, etc. Y también, sobre todo, una reconstrucción editorial donde ya no tendremos a esas grandes empresas, sino más bien a una serie de emprendimientos independientes, entre publicaciones periódicas y libros, que tienden a unirse en estrategias comunes que les permitan mantenerse en el tiempo y a la vez proponer un plan editorial más ambicioso. En síntesis, un proceso de profesionalización posindustrial.

También se recomponen ciertos lazos europeos, casi siempre con Francia, pero también con Italia en el caso de autores pertenecientes a generaciones anteriores, como Enrique Breccia y Robin Wood, entre otros. Un ejemplo claro es el de Diego Agrimbau, que retoma la tradición del guionista al estilo Trillo y logra publicar varias obras en Francia, las cuales luego son republicadas en Argentina, de manera paulatina y a veces con cierto retraso a la aparición original, pero son publicadas al fin.

Otra cuestión interesante es la recuperación de esa misma tradición historietística que estaba incompleta, porque muchas de las obras nunca se habían publicado en Argentina porque se las había publicado de manera parcial o porque estaban en revistas que tenían ya treinta años. En los últimos diez años, o incluso menos, se produjo una reimpresión de trabajos de los Breccia - Alberto, Enrique y Patricia-, de cosas de Oesterheld, de Trillo, de Muñoz y Sampayo... No sé si llega demasiado tarde o no, la cuestión es que hoy tenemos la posibilidad de leer esas obras, que durante mucho tiempo sabíamos de su existencia, pero se nos hacían inalcanzables.

Y después, como dije, generaciones de nuevos autores. Cambia un poco la brújula de qué significa contar en historieta: hay cosas más autobiográficas, pero sobre todo más personales. Hay gente que hace desde manga y superhéroes hasta otros más inclasificables. Creo que eso es lo mejor: una variedad y una diversidad como nunca las hubo en la historia de la historieta argentina y, posiblemente, latinoamericana. De hecho, hay muchos autores/as de Sudamérica que producen desde Argentina, o que acostumbran participar en una red de eventos donde los Estados suelen tener un rol importante al momento de mantener una regularidad, y eso convive con una movida más independiente donde esos mismos autores están presentes.

Cosas como Comicópolis y Crack Bang Boom en Argentina coexisten con Dibujados, un festival autogestionado. Y hay otros eventos en Chile, Uruguay, Perú, Bolivia, Colombia, con mayor o menor regularidad, donde se cruzan los autores, comparten conferencias, intercambian sus obras y sus dibujos. Yo creo que se ha reforzado - y mantenido- una idea solidaria de la comunidad de historietistas. Esto siempre existió, pero en el marco de una industria. Acá no hay industria, pero sí hay producción y trabajo; todos están entre el mercado y su arte y los circuitos más oficiales y más alternativos, sin que eso tenga que ser mutuamente exclu- 
yente. Dentro de esos circuitos se cuenta Europa, con presentaciones de libros en España y Francia, y también el trabajo for export a Estados Unidos, desde lo más mainstream hasta cosas extrañas, como Fantagraphics publicando El Eternauta o autores contemporáneos, como Ezequiel García y Lucas Varela, y según tengo entendido publicarán Mort Cinder.

Es un momento extraño y particular que llegaría hasta 2015. El cambio de gobierno y el abandono de ciertas políticas de Estado más proteccionistas o interesadas en estos sectores culturales hacen que, por primera vez en una década, el circuito editorial de la historieta esté frente a un desafío que implica su supervivencia. Se ha llegado a números de producción interesantes - que, por supuesto están alejadísimos en términos cuantitativos de una tirada regular de las antiguas publicaciones masivas, pero que implican a su vez la mayor producción desde el quiebre industrial一, y ahora la pregunta es cómo mantener eso. Es esperable una retracción en el consumo y en la oferta, porque ambas cosas están conectadas.

Habrá que ver qué estrategias en común se adoptan, cuán efectivas son, qué editoriales y revistas sobreviven y cuáles no... Una ventaja relativa es que, a diferencia de los noventa, cuando las importaciones eran muy baratas porque había una paridad peso/dólar, ahora las ediciones extranjeras - en general, españolas - son dos o tres veces más caras que una edición local. Es cierto que nadie en Argentina puede publicar a Ware o Clowes, pero si uno tiene en cuenta que un peso vale veinte veces menos que un euro, eso quiere decir que al precio de tapa de una publicación de La Cúpula - por poner un ejemplo- se le suman el flete y el margen de ganancia de quien lo vende, y a eso se lo multiplica por veinte. El precio no va a bajar de unos $\$ 600$, mientras que el precio promedio de un libro de historieta local - y con muy buena calidad - está alrededor de $\$ 250$. Eso permite cierto aire a las editoriales argentinas; habrá que ver cómo lo aprovechan.

Amadeo Gandolfo: Pablo resumió bastante bien lo que sucedió en los noventa, que a menudo son vistos como una verdadera catástrofe por el espectro entero del campo historietístico local, pero que también fueron un momento de experimentación y ampliación. Las revistas y fanzines de corta vida y periodicidad irregular fueron el semillero de un montón de artistas que terminaron siendo parte fundamental del «renacimiento» de la escena a partir del 2005.

Lo llamativo de los noventa fue que aquello que aniquiló en gran parte la industria local -las políticas de importación de material extranjero, superhéroes, manga y ediciones españolas - también permitió, para toda una generación, acceder a la lectura de material en cantidades inusitadas en tiempos preinternet. Eso se refleja bien en las principales revistas del período: tenés El Lápiz Japonés, con una fuerte impronta del diseño gráfico, pero también un ojo puesto en la $R A W$ de Spiegelman y Mouly; ;Suélteme!, que agrupa dibujantes con bastante influencia de los underground, de las tiras de prensa norteamericanas más salvajes, pero también del humor gráfico argentino clásico; y El Tripero, compuesta por una camada de estudiantes de Alberto Breccia, que ciertamente llevan algo de su impronta, pero la mixturan con el cómic independiente norteamericano en blanco y negro de mitad de los ochenta y principios de los noventa - Burns, Doucet, Clowes. 
Es importante también señalar que la crisis que pone fin a una forma de hacer historieta en Argentina es estructural al país. La crisis del 2001 representa un crack en más de un sentido, y en el caso de la historieta es un borrón y cuenta nueva en cuanto a las lógicas comerciales, formatos y viejas casas editoras, aunque gran parte de la generación que se crio al calor de esos noventa caóticos siguiera activa luego.

Coincido con la apreciación cronológica al respecto de los inicios de la más reciente etapa de la historieta argentina; 2005 es un buen año para marcar los principios de una incipiente recuperación, que por supuesto no fue ni es lineal ni poco conflictiva. Una buena señal de ello es el lugar contradictorio que ocupa la segunda etapa de la revista Fierro: por un lado, es una revista absolutamente central, ya que durante una década fue la única publicación periódica, de aparición mensual y distribución nacional en los quioscos, dedicada a la historieta, que produjo por su misma lógica una gran cantidad de obra nueva; por otro lado, es cuestionada y criticada por su línea editorial, por la repetición de algunos artistas, por sus precios de página y, en definitiva, por su misma centralidad, a la cual se le reclama ser representativa y funcionar como una industria que ya no existe.

Por otra parte, como mencionó Pablo, tenemos la creación y el asentamiento de una variedad de nuevos proyectos editoriales que apuestan por el libro como contenedor privilegiado de la historieta, y que buscan generar catálogos robustos que se vendan de forma perenne en dos grandes outlets: las comiquerías ${ }^{4}$ y los eventos. Muchas de estas editoriales se manejan de forma seria y concienzuda, generan vínculos duraderos con los artistas y existen más como cooperativas horizontales que en la estructura piramidal de antaño.

La comiquería es otro fenómeno que se asienta de forma definitiva en los noventa en Argentina, parte de ese proceso de importación contradictorio, y que muta en los dos mil para convertirse en un engranaje de la «industria» local. Si bien en los noventa la comiquería era básicamente el sitio de lo europeo, norteamericano y japonés, la mayoría de los locales existentes en la actualidad mezclan alguna proporción de cómic mainstream o indie con las producciones locales. La gran cantidad de publicaciones - alrededor de doscientos libros por año en los últimos dos o tres años- además garantiza y reclama un lugar en las repisas. Asimismo, muchas comiquerías de Buenos Aires se han convertido en centros de actividad, con presentaciones de libros, talleres, fiestas y otras situaciones de sociabilidad.

Los eventos, por su parte, proliferaron y, al igual que en los Estados Unidos, son muy necesarios para la economía de la escena. Las editoriales intentan cronometrar sus lanzamientos con los mismos, y pueden llegar a hacer una diferencia gracias a ellos. En los últimos años, algunos de ellos han sufrido un proceso de reconversión y crisis que lleva a preguntarse por la posibilidad de sostenimiento de este circuito económico y social.

Ante esto, también se presenta la cuestión de la audiencia. Pareciera que, de algún modo u otro, (casi) todo participante de la audiencia de la historieta argentina es a la vez un pro-

${ }^{4}$ Librería especializada en cómic. 
ductor o actor de la misma. El viejo sueño del lector pasivo ha muerto, y eso se refleja no solamente en la continua aparición de nuevos artistas producto de talleres, de la lectura y de la escena fanzinera — que es enorme y variadísima-, sino también en las batallas intestinas que se siguen sosteniendo, a veces con niveles de histeria bastante altos, alrededor de lo que es bueno y malo, la definición de lo que debería ser la historieta y las mejores prácticas comerciales para la misma.

Algunas cuestiones se mantienen sin respuesta. Por un lado, la excesiva concentración de la escena alrededor de Buenos Aires, un problema que no es exclusivo de la historieta y que responde a las características centralizadoras de nuestro país. Hubo y hay escenas y editoriales importantes en Córdoba y Rosario, que agregan una necesaria variedad; también hay grupos en el Sur del país. Pero Buenos Aires sigue siendo una cabeza de Goliat en la cual convergen necesariamente los eventos, las presentaciones, los éxodos de artistas, por lo que armar algo desde «el interior» es a veces remar contra dificultades mucho más grandes que en la capital.

Otro dilema irresuelto es la relación del cómic con las artes plásticas y con aquellas definiciones que lo violentan. La aparición de artistas muy jóvenes que dinamitan la narrativa y las técnicas, y que expresan voluntariosa ignorancia de los códigos e historia del cómic, ha despertado debates acerca de su valor, de la caracterización de su obra como historieta y de su adhesión a largo plazo a la forma. En algunos casos, los cuestionamientos parten de una posición que encuentra en el conocimiento y respeto a la historia del medio un resarcimiento frente a la (casi) inexistencia de recompensa económica. «Ya que no hay plata, al menos hay que respetar la historia de esta forma que hacemos desde el corazón».

Asimismo, un fenómeno muy reciente y muy esperanzador es la aparición de corrientes feministas y queer en la escena local. Autodefiniéndose de manera frontal y tematizando su experiencia personal, organizando eventos, mesas y publicaciones que dan visibilidad al colectivo y atrayendo a franjas de audiencia que hasta ahora se habían mostrado poco interesadas, este movimiento da pistas sobre una nueva revitalización siempre en marcha.

A esto se suman los fenómenos de ediciones extranjeras de material y de visitas de autores y editores a Argentina en diferentes eventos, que parecen interesarse y fascinarse por la escena local, quizás ayudando — quién sabe si es así y cuánto- a generar una mayor conciencia global de una «escuela argentina».

En definitiva, muchas cosas están pasando, muchas publicaciones, mucha efervescencia, pero con la pregunta repetida todo el tiempo de para quién, de cómo aumentar y preservar el público; $y$ con el miedo usual de todo emprendimiento cultural en Argentina a que una nueva crisis económica obligue a comenzar todo desde cero o deje lo existente en una situación precaria. Pero las voces, las ideas y los estilos que se encuentran activos y proliferan, creo, no tienen nada que envidiarles a las escenas mucho más grandes, como la de Estados Unidos o Canadá.

Gerardo Vilches: Veo muchos puntos en común entre España y Argentina, por lo que describís, en el siglo xxi. Quizás, en el caso español, los indicios de recuperación del sector 
se dejaron notar un poco antes, cuando, en un panorama dominado por las ediciones de material foráneo, aparecen algunas nuevas editoriales que apuestan por el formato de libro. De Ponent (1998-2016), Sins Entido (1999-2014) y Astiberri (2001-) son de las primeras que se deciden a arriesgar con este «nuevo» formato, que parecía querer rescatar del conformismo del modesto cómic grapado dirigido a librerías especializadas. Desde entonces, se ha experimentado una ampliación del público lenta, con altibajos, pero creo que constante. E1 cómic ha comenzado a venderse también en grandes cadenas y en librerías literarias, han ido apareciendo becas y ayudas institucionales — demasiado escasas aún-, se han programado exposiciones en museos de arte, los medios de comunicación han prestado cada vez más atención al sector... Y la producción española ha crecido mucho en estos diecisiete años, gracias a la apuesta por parte de las editoriales mencionadas y otras que han ido apareciendo por el camino, así como algunas históricas como La Cúpula, Glénat - ya desaparecida- o Norma Editorial. Poco a poco, se ha perdido el miedo a publicar libros de gran formato, así como a reeditar, mantener en catálogo los títulos... Se ha ido adoptando el modelo literario, en suma, con la novela gráfica como el estándar de publicación profesional, aunque existen también pequeñas iniciativas que publican aún material en comic book.

Paralelamente a ese resurgimiento del sector a través de estas coordenadas que acabo de explicar, también se ha incrementado mucho la cifra de autores que trabajan para las grandes industrias estadounidense y francobelga, pero también la de aquellos que se autoeditan o trabajan en proyectos pequeños, que se mueven en internet y en el creciente circuito de ferias alternativas a los grandes salones del cómic de modelo tradicional.

El fenómeno que comenta Amadeo, de la irrupción de un grupo de artistas que comienzan a hacer cómic sin conocerlo en profundidad, también está sucediendo aquí: jóvenes autores y autoras, muchas veces procedentes de Bellas Artes, que comienzan a hacer fanzines o a publicar con editoriales pequeñas tras haber leído muy pocos cómics o, incluso, haberse iniciado en el medio en la edad adulta — en contraposición al típico dibujante que leía tebeos desde pequeño- En consecuencia, no sienten que deban nada a la tradición, ni aspiran a incorporarse a una industria con la que no se identifican y que, además, se encuentra en un momento de crisis. Pienso que todo esto, en realidad, responde a una tendencia internacional; de hecho, este tipo de dibujantes suelen estar en contacto con colectivos y artistas de otros Estados.

El caso español, desde mi punto de vista, también responde a lo que habéis apuntado: aunque, desde los años noventa, haya experimentado un crecimiento innegable, las ventas no son aún suficientes como para que una parte significativa de los autores puedan vivir de sus libros. Esto, que, por otra parte, es común a escritores, músicos o actores, se ha convertido en mantra, a pesar de que sí existen muchos profesionales que, alternando el cómic y la ilustración, logran ganarse la vida. Hay que tener en cuenta, en todo caso, la crisis económica brutal que experimenta España desde 2008, aproximadamente, que cortó en seco la progresión del sector y frenó las ayudas institucionales. Estamos, en mi opinión, en un momento artísticamente extraordinario. Nunca ha habido tanta variedad estilística ni tanta calidad, ni oportunidades de publicación en cualquier tipo de formato o circuito. El reto ahora, como 
Historia de dos industrias: un debate en torno a la historieta argentina y española II

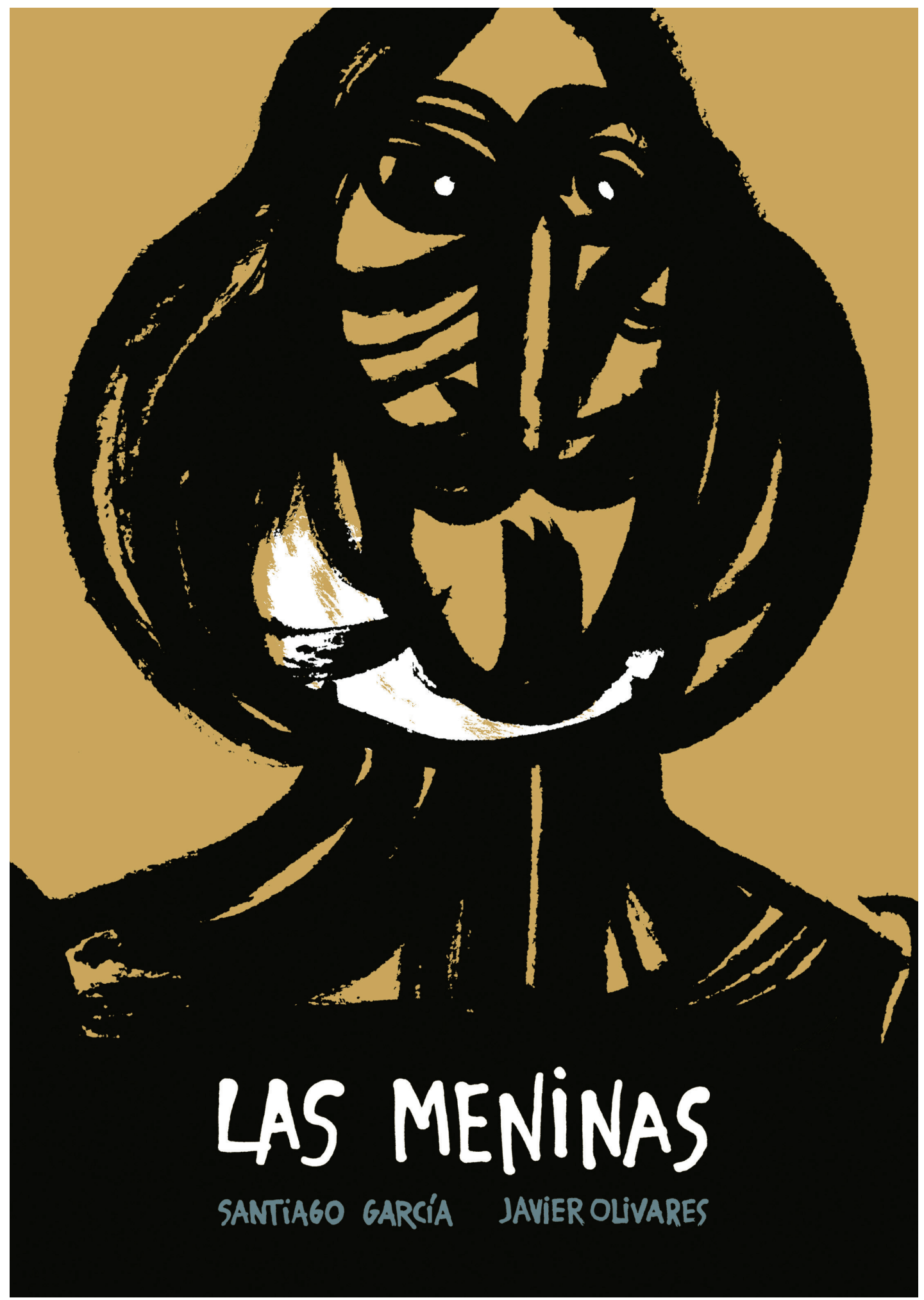

FIG. 12. García, S. y Olivares, J. Las meninas.

Bilbao, Astiberri, 2014. 
en el caso argentino, supongo, es que el público crezca poco a poco: llegar definitivamente, en suma, a ese «lector pasivo» que menciona Amadeo.

Amadeo Gandolfo: Como reflexión de cierre, solamente me interesa destacar la resiliencia de ambas escenas. Que hoy en día alguien se dedique a hacer historietas es un poco una locura y un milagro. $\mathrm{Y}$ a la vez hay algo irresistible que sigue consiguiendo que se hagan historietas. Coordinamos una mesa recientemente en el Festival Fanzín, un evento realizado en el Centro Cultural Rojas, y tanto los artistas que se habían iniciado en los ochenta,

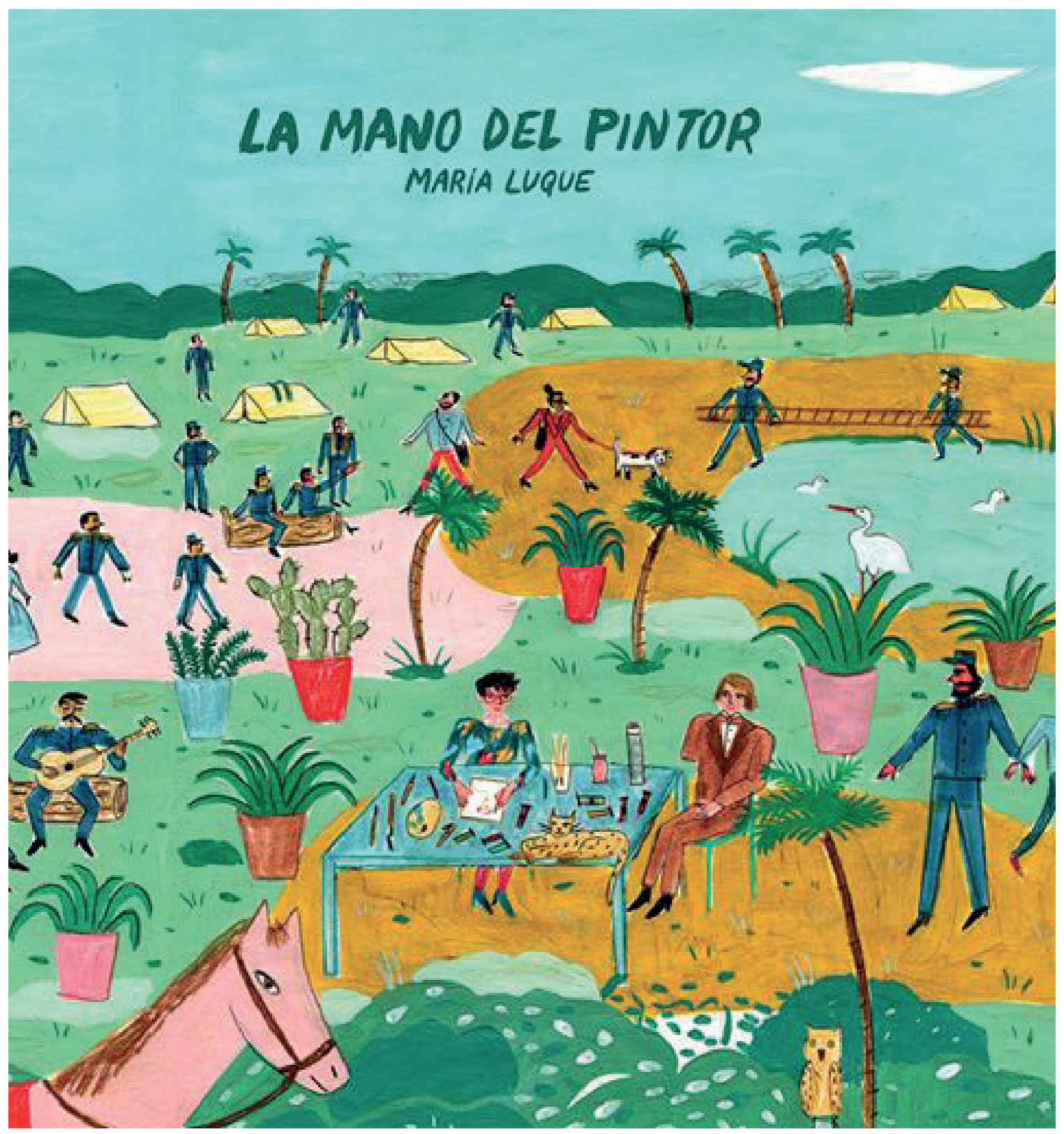

FIG. 13. LuQue, M. La mano del pintor. Buenos Aires, Editorial Sigilio, 2016. 
como en los noventa o en los dos mil, destacaban algunas cosas: por un lado, la importancia del recurso a la autoedición como una forma de obtener libertad, pero también como una especie de último salvo frente a la inexistencia de estructura; y, por otro lado, cómo se reacomodó la industria alrededor del libro, con editoriales que surgieron justamente al calor del colapso, aprendiendo en el largo plazo las lecciones que les sirvieron a los fanzines y las ediciones autogestionadas. Y, a la vez, en la feria que sucedía afuera del auditorio había una barbaridad de publicaciones independientes, realizadas con una multiplicidad de formatos y estilos, por un montón de artistas que apenas sí conocíamos. A lo que voy es que todo puede ser de una fragilidad enorme, y el nuevo paradigma en el que no existen redacciones, revistas, plazos de entrega y remuneración fija aún hoy, veinte años después de su lenta imposición, todavía desconcierta, pero pareciera que, sin embargo, hay suficiente efervescencia y, sobre todo, atractivo en la producción y la superficie de la historieta para seducir a una horda diversa de dibujantes.

Pablo Turnes: Totalmente de acuerdo. Uno se da cuenta de que el festival es una especie de organismo, fluye, tiene diferenciales — una charla, un DJ, la feria en sí, la gente tomando cerveza, todo en simultáneo- - Y si pasa eso es porque la historieta está viva, tal vez más viva que nunca. Creo que hay que historizar esas experiencias para que no se diluyan en

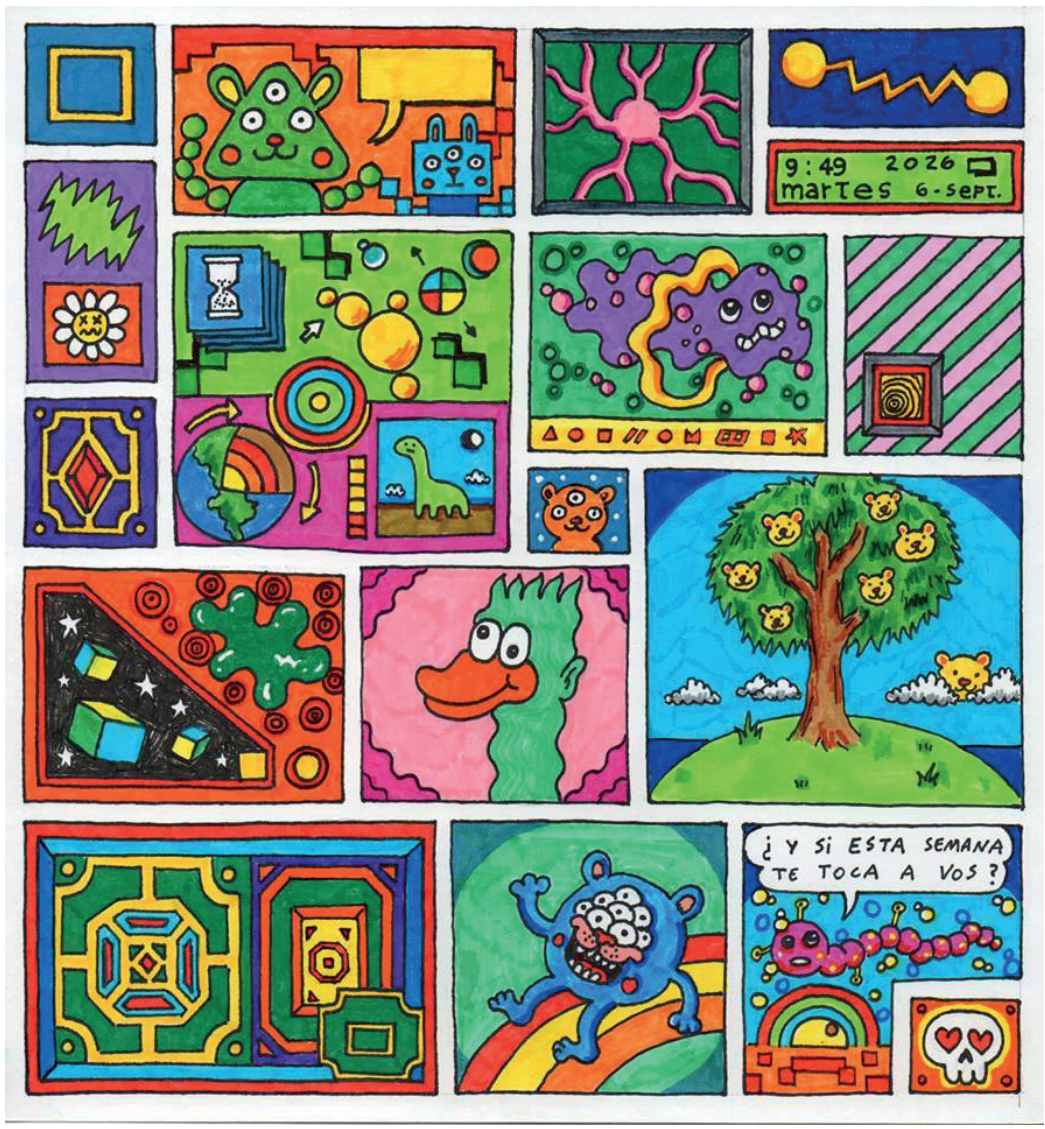

FIG. 14. Juan Vegetal. «Mil años después».

Rosario, 2016. 
solo eso y ya, una especie de souvenir. Hay una historia, una cadena de cosas que se han ido sucediendo y que en algún punto están conectadas. Tal vez esa sea nuestra contribución: historizar. Entender lo que hicieron los otros antes que uno nos permite defendernos en momentos en que no solo hay que sobrevivir, sino aprender a hacer mejor las cosas. En eso estamos. 